\author{
UNIVERSIDADE DE SÃO PAULO \\ ESCOLA DE ENGENHARIA DE SÃO CARLOS \\ INSTITUTO DE FÍSICA DE SÃO CARLOS \\ INSTITUTO DE QUÍMICA DE SÃO CARLOS \\ GRUPO DE FÍSICO-QUÍMICA ORGÂNICA
}

LUCAS PONEZ DA MOTA

\title{
PREPARAÇÃO E CARACTERIZAÇÃO DE ELETRÓLITOS SÓLIDOS POLIMÉRICOS À BASE DE GELATINA COMERCIAL PARA APLICAÇÃO EM CÉLULAS SOLARES
}

SÃO CARLOS 



\section{LUCAS PONEZ DA MOTA}

\section{PREPARAÇÃO E CARACTERIZAÇÃO DE ELETRÓLITOS SÓLIDOS POLIMÉRICOS À BASE DE GELATINA COMERCIAL PARA APLICAÇÃO EM CÉLULAS SOLARES}

Dissertação apresentada ao Programa de PósGraduação Interunidades em Ciência e Engenharia de Materiais da Universidade de São Paulo, para a obtenção do título de mestre em Ciência e Engenharia de Materiais.

Área de concentração: Desenvolvimento, Caracterização e Aplicação de Materiais

Orientadora: $\operatorname{Prof}^{\mathrm{a}} \mathrm{Dr}^{\mathrm{a}}$ Agnieszka Joanna Pawlicka Maule

SÃO CARLOS

2010 


\begin{abstract}
AUTORIZO A REPRODUÇÃO E DIVULGAÇÃO TOTAL OU PARCIAL DESTE TRABALHO, POR QUALQUER MEIO CONVENCIONAL OU ELETRÔNICO, PARA FINS DE ESTUDO E PESQUISA, DESDE QUE CITADA A FONTE.
\end{abstract}

Ficha catalográfica elaborada pelo Serviço de Biblioteca e Informação IFSC/USP

Mota, Lucas Ponez da.

Preparação e caracterização de eletrólitos solidos poliméricos à base de gelatina comercial para a aplicação em celulas solares / Lucas Ponez da Mota; orientadora Agnieszka Joanna Pawlicka Maule.--São Carlos, 2010.

$84 \mathrm{p}$.

Dissertação (Mestrado - Programa de Pós-Graduação em Interunidades Ciência e Engenharia de Materiais. Área de Concentração: Desenvolvimento, Caracterização e Aplicação de Materiais) - Escola de Engenharia de São Carlos, Instituto de Física de São Carlos, Instituto de Química de São Carlos da Universidade de São Paulo

1. Gelatina. 2. Eletrólitos. 3. Condutividade. 4. Célula solar. I. Título. 


\title{
FOLHA DE APROVAÇÃO
}

\section{Lucas Ponez da Mota}

\begin{abstract}
Dissertaçăo apresentada ao Programa de Pós-Graduação em Ciência e Engenharia de Materiais da Universidade de Săo Paulo para obtençăo do título de Mestre em Ciência e Engenharia de Materiais.

Área de Concentração: Desenvolvimento, Caracterização e Aplicaçăo de Materiais
\end{abstract}

Aprovado em: 23/02/2010

\section{Comissão Julgadora}

Profa. Dra. Agnieszka Joanna Pawlicka Maule

Instituiçăo: IQSC/USP

Assinatura

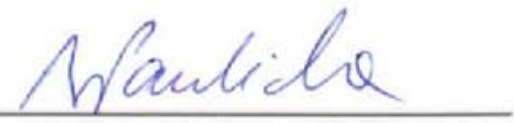

Profa. Dra. Sandra Helena Pulcinelli

Instituição: UNESP

Assinatura

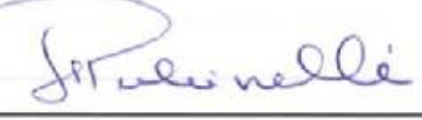

Prof. Dr. Jose Pedro Donoso Gonzalez

Instituiçāo: IFSC/USP

Assinatura

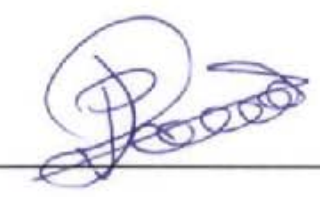




Essa dissertação é inteiramente dedicada ao meu avô Diocelino José Ponês, símbolo de sabedoria, carinho e dedicação por todos da família. Um grande homem que representa parte do que sou. 



\section{AGRADECIMENTOS}

Gostaria de demonstrar toda a minha gratidão pela a $\operatorname{Prof}^{a} \operatorname{Dr}^{a}$ Agnieszka Joanna Pawlicka Maule, que teve toda a paciência do mundo para me orientar, por saber chamar a minha atenção sem que isso me deixasse envergonhado ou até mesmo triste e acima de tudo gostaria de agradecer por todo conhecimento passado a mim.

À minha querida mãe Adarci Ponez da Mota, por ser a pessoa mais importante da minha vida e simplesmente por estar ao meu lado durante o tempo do mestrado que foram os dois anos mais difíceis da minha vida.

À minha avó Aparecida Destefani José Ponês, mesmo com o pouco tempo em que passamos juntos, esses momentos foram de grande alegria (os poucos que tive).

Aos meus tios dos quais eu tenho uma grande admiração que são eles: Mário Alberto Graça, Márcio José Ponês, Edna José Ponês Graça e Edna Enz Ponês, pessoas com quem passei momentos inesquecíveis durante o tempo do mestrado.

À minha futura noiva Ana de Véras Insfran.

Ao Éder Cicero Adão Simêncio por me ajudar a tomar uma decisão crucial para a conclusão do meu mestrado

Às grandes colegas de laboratório Ritamara Isis de Mattos e Ellen Raphael, por me ensinarem todo o processo experimental que envolveu a minha pesquisa.

À Prof ${ }^{\mathrm{a}} \mathrm{Dr}^{\mathrm{a}}$ Ana Flávia Nogueira IQ-UNICAMP por colaborar com a nossa pesquisa cedendo o laboratório onde as análises de eficiência da célula solar foram realizadas.

Ao Flávio Santos Freitas IQ-UNICAMP, por me ajudar no laboratório e na montagem dos dispositivos da célula solar.

À Denise Toledo Bonemer de Salvi (IQ-UNESP) por ceder o aparelho para as análises de DSC.

Ao amigo Danilo Borges Villarino de Castro, por me fazer inúmeros favores além de me ajudar na adoção do Escritório (meu cachorro).

E por último e não menos importante, gostaria de agradecer ao meu pai Wander Jacinto da Mota, que no início do mestrado me deu todo o suporte necessário para que eu conseguisse residir em São Carlos/SP por alguns meses sem receber bolsa, que infelizmente foi vítima de um AVE e hoje não tem condições de perceber a importância do patamar que atingi. 

"O Homem aqui não vive, sobrevive." Rodolfo Abrantes 



\section{RESUMO}

MOTA, L. P. Preparação e caracterização de eletrólitos sólidos poliméricos à base de gelatina comercial para aplicação em células solares. 2010. 84p. Dissertação (Mestrado) - Escola de Engenharia de São Carlos, Instituto de Física de São Carlos, Instituto de Química de São Carlos, Universidade de São Paulo, São Carlos, 2010.

O presente trabalho visou estudar e caracterizar eletrólitos sólidos poliméricos (ESP) à base de gelatina plastificada com glicerol, entrecruzada com formaldeído e contendo $\mathrm{Lil} / \mathrm{I}_{2}$ para a aplicação em células solares.

O objetivo foi obter os eletrólitos à base de gelatina comercial (Dr. Oetker ${ }^{\circledR}$ ) de origem animal, uma vez que a mistura de aminoácidos presentes na mesma apresenta propriedades mecânicas interessantes e torna-se um gel transparente na região do visível. Glicerol foi usado para promover a plastificação e o formaldeído para promover as ligações cruzadas na mistura das proteínas aumentando a estabilidade e resistência dos filmes. As fontes iônicas foram o Lil. $2 \mathrm{H}_{2} \mathrm{O}$ e $\mathrm{I}_{2}$ na proporção de $10: 1 \mathrm{~m} / \mathrm{m}$.

O estudo revelou que as amostras apresentaram os valores de condutividade iônica de $7,68 \times 10^{-5} \quad \mathrm{~S} . \mathrm{cm}^{-1}, \quad 6,38 \times 10^{-5} \quad{\mathrm{~S} . \mathrm{cm}^{-1}}^{-1} \quad 8,81 \times 10^{-5} \quad{\mathrm{~S} . \mathrm{cm}^{-1}}$, $9,97 \times 10^{-5} \mathrm{~S}^{-\mathrm{cm}^{-1}}$ e $7,87 \times 10^{-5}{\mathrm{~S} . \mathrm{cm}^{-1}}$ dependendo da concentração da mistura Lil. $2 \mathrm{H}_{2} \mathrm{O} / \mathrm{I}_{2}$. As medidas de condutividade em função da temperatura mostraram que 0 mecanismo que governa a condutividade é do tipo VTF. As análises de estrutura das membranas por difração de Raios- $X$ mostraram o caráter predominantemente amorfo e as análises térmicas (DSC) os valores da temperatura de transição vítrea $\left(T_{g}\right)$ da ordem de $-77^{\circ} \mathrm{C}$. A transparência das amostras de 80 a $90 \%$ foi confirmada por espectroscopia UV-Vis e as análises microscópicas (MEV) mostraram a presença de pequenos pontos brancos nas superfícies das amostras. Os eletrólitos aplicados em um pequeno protótipo de célula solar renderam um máximo de $0,15 \%$ de eficiência.

Palavras-chave: Gelatina, Eletrólitos, Condutividade, Célula Solar. 



\section{ABSTRACT}

MOTA, L. P. Preparation and characterization solid polymer electrolytes based of commercial gelatin for application in solar cells. 2010. 84p. Dissertation (Master) Escola de Engenharia de São Carlos, Instituto de Física de São Carlos, Instituto de Química de São Carlos, Universidade de São Paulo, São Carlos, 2010.

This present work aimed study and characterization of solid polymer electrolytes (SPE) based on gelatin plasticized with glycerol, crosslinked with formaldehyde and containing $\mathrm{Lil} / \mathrm{I}_{2}$ for application in solar cells.

The plan was to get the electrolytes based on commercial gelatin (Dr. Oetker ${ }^{\circledR}$ ) of animal, since the mixture of amino acids present interesting mechanical properties and becomes a transparent gel in the visible region. Glycerol was used to promote plasticization and formaldehyde to promote cross-linking of the mixture of proteins leading to increase the stability and strength of the films. The ion sources were $\mathrm{Lil}_{2} 2 \mathrm{H}_{2} \mathrm{O}$ and $\mathrm{I}_{2}$ at a ratio of $10: 1 \mathrm{~m} / \mathrm{m}$.

The study revealed that the samples showed the values of ionic conductivity of $7.68 \mathrm{x}$

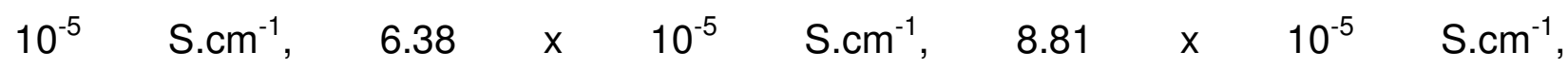

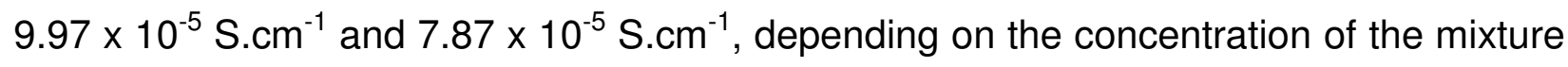
Lil. $2 \mathrm{H}_{2} \mathrm{O} / \mathrm{I}_{2}$. Ionic conductivity measurements as a function of temperature revealed VTF conducting model. X-ray diffractogramms showed the predominantly amorphous nature and thermal analysis (DSC) values of the glass transition temperature ( $\mathrm{Tg}$ ) of about $-77^{\circ} \mathrm{C}$. The transparency of the samples of 80 and $90 \%$ was confirmed by UVVis and the microscopic analysis (SEM) showed the presence of small white points in the surface of the samples. The electrolytes used in small solar cell prototypes yielded a maximum of $0.15 \%$ efficiency.

Keywords: Gelatin, Gel Electrolytess, Ionic Condutivity, Solar Cell. 



\section{LISTA DE FIGURAS}

Figura 1- Estrutura quaternária do colágeno 25

Figura 2 - lustração da forma de coordenação do lítio com o oxigênio presente nos aminoácidos 29

Figura 3 - Esquema de montagem de uma célula solar 31

Figura 4 - Representação de funcionamento de uma célula solar do tipo Gratzel (DSSC) com o processo de transferência eletrônica para a conversão de energia solar em energia elétrica 32

Figura 5 - Espectro eletromagnético 36

Figura 6 - Comportamento gráfico de uma radiação eletromagnética 37

Figura 7 - Espectro no ultravioleta e visível de uma substância hipotética 38

Figura 8 - $\quad$ Análise numérica utilizando eixos imaginário e real 40

Figura 9 - Comportamento ideal do gráfico de Nyquirst 41

Figura 10 - Demonstração da difração de Raios X, num material 43

Figura 11 - Difratograma de um material cristalino 44

Figura 12 - Difratograma de um material amorfo 44

Figura 13 - Dois tipos de vibrações das moléculas 45

Figura 14 - Esquema de um espectrômetro de infravermelho com transformada de Fourier 46

Figura 15 - Espectro de infravermelho de uma substância orgânica não Identificada 47

Figura 16 - Banda correspondente à hidroxila presente em uma substância orgânica 47

Figura 17 - Exemplo de uma curva DSC com as transições características 49

Figura 18 - Exemplo para determinar a $T_{g} 50$

Figura 19 - Componentes de um microscópio eletrônico de varredura 52

Figura 20 - Micrografia eletrônica de varredura de um ESP 52

Figura 21 - Célula eletroquímica com três eletrodos $\quad 54$

Figura 22 - Comportamento ideal apresentado pela célula solar 54

Figura 23 - Estrutura molecular a Ftalocianina de Ferro Tetracarboxilada 55 
Figura 24 - Espectro no infravermelho da amostra de G4

Figura 25 - Variação da condutividade em função do tempo de exposição da amostra G4 ao ambiente do laboratório

Figura 26 - Difratogramas de G4 realizados em dias diferentes 60

Figura 27 - Valores de condutividade para diferentes porcentagens de Lil// 262

Figura 28 - Valores das condutividades iônicas em função do inverso da temperatura, em triplicata da amostra G1

Figura 29 - Valores das condutividades iônicas em função do inverso da temperatura, em triplicata da amostra G2

Figura 30 - Valores das condutividades iônicas em função do inverso da temperatura, em triplicata da amostra G3

Figura 31 - Valores das condutividades iônicas em função do inverso da temperatura, em triplicata da amostra G4

Figura 32 - Valores das condutividades iônicas em função do inverso da temperatura, em triplicata da amostra G5

Figura 33 - Valores das condutividades iônicas em função do inverso da temperatura, em triplicata da amostra ESP

Figura 34 - Ajuste dos valores de condutividade iônica de acordo com o modelo VTF, onde To=Tg-50K

Figura 35 - Janela de Potencial apresentada pela amostra G4

Figura 36 - Valores de condutividades iônicas em função do inverso da temperatura do primeiro e segundo ciclo de aquecimento da amostra G4.70

Figura 37 - Espectros e ultravioleta e visível dos ESPs de G1-G5 71

Figura 38 - Difratograma das amostras G1- G5 72

Figura 39 - Curva de DSC da amostra G1 73

Figura 40 - Curva de DSC da amostra G2 74

Figura 41 - Curva de DSC da amostra G3 74

Figura 42 - Curva de DSC da amostra G4 75

Figura 43 - Curva de DSC da amostra G5 75

Figura 44 - Micrografia da amostra G1 76 
Figura 45 - Micrografia da amostra G2

Figura 46 - Micrografia da amostra G3

Figura 47 - Micrografia da amostra G4

Figura 48 - Micrografia da amostra G5.

Figura 49 - Curva da intensidade de corrente versus voltagem para a célula solar iluminada com potência de $10 \mathrm{~mW} . \mathrm{cm}^{-2}$

Figura 50 - Curva da intensidade de corrente versus voltagem para a célula solar iluminada com potência de $100 \mathrm{~mW} . \mathrm{cm}^{-2}$ 



\section{LISTA DE TABELAS}

Tabela 1 - Propriedades físico-químicas de alguns sais e ácido acético 29

$\begin{array}{lll}\text { Tabela } 2 \text { - Valores de sal adicionado } & 37\end{array}$

Tabela 3 - Valores de condutividades iônicas das amostras com diferentes quantidades de glicerol

Tabela 4 - Valores de condutividade iônica para cada medida para diferentes quantidades de sal de lítio

Tabela 5 - Valores médios de condutividade para diferentes quantidades do par Redox

Tabela 6 - Valores de Energia de Ativação dos ESPs

Tabela 7 - Valores de espessura das amostras dos ESPs

Tabela 8 - Temperatura de transição vítrea em das amostras G1-G5 



\section{SUMÁRIO}

1 - INTRODUÇÃO 23

1.1 - Métodos espectroscópicos de caracterização de ESP 23

1.2 - Espectroscopia no Ultravioleta e Visível 24

1.3- $\quad$ Espectroscopia de Impedância Eletroquímica 25

1.4 - Espectroscopia de Raios X 26

1.5 - Espectroscopia de Absorção no Infravermelho 27

1.6 - Método térmico para a caracterização de ESPs 28

1.7 - Calorimetria Exploratória Diferencial 30

2 - OBJETIVOS 33

3 - MATERIAIS E MÉTODOS $\quad 35$

3.1 - Métodos espectroscópicos de caracterização de ESP 35

3.1 .1 - Espectroscopia no Ultravioleta e Visível 37

3.1.2- Espectroscopia de Impedância Eletroquímica 39

3.1.3 - Espectroscopia de Raios X 42

3.1.4 - Espectroscopia de Absorção no Infravermelho 45

3.2 - Método térmico para a caracterização de ESPs 48

3.2.1 - Calorimetria Exploratória Diferencial 48

3.3 - $\quad$ Métodos eletrônicos para a caracterização de ESPs 50

3.3.1 - Microscopia Eletrônica de Varredura $\quad 50$

3.3.2 - Voltametria de Varredura Simples 53

4- $\quad$ RESULTADOS E DISCUSSÃO

4.1 - Determinação da quantidade de Glicerol $\quad 57$

4.2 - $\quad$ Condutividade dos EPSs 59

4.2.1- Teste da Condutividade $\quad 59$

4.2.2 - Valores de Condutividade dos ESPs $\quad 61$

4.2.3 - Janela Eletroquímica 68

4.2.4 - Teste do Resfriamento $\quad 69$

4.3 - $\quad$ Análise no Ultravioleta e Visível 70

4.4 - Difração de Raios X 72 
4.5 - $\quad$ Calorimetria Exploratória Diferencial 73

4.6 - Microscopia Eletrônica de Varredura $\quad 76$

4.8 - $\quad$ Análise da Eficiência da Célula Solar 78

5 - $\quad$ CONCLUSÕES 79

REFERÊNCIAS 


\section{INTRODUÇÃO}

\subsection{Obtenção de Eletrólitos Sólidos Poliméricos}

Até os anos 70 do século $X X$ muitos polímeros sintéticos foram considerados como sendo materiais isolantes até que $\mathrm{H}$. Schirakawa, A. MacDiarmid e A. Heeger (prêmios Nobel de Química em 2000) demonstraram que polímeros que possuem ligações duplas conjugadas, como poli(acetileno) podem conduzir elétrons. Também nesta época começaram ser pesquisados por P. Wright e M. Armand ${ }^{1}$ polímeros que podem dissolver sais inorgânicos e com isso promover a condutividade iônica mudando, com isso, a característica dos polímeros de isolantes para condutores. O primeiro eletrólito polimérico a ser apresentado foi obtido com poli(óxido de etileno) (PEO). Nesses estudos foi demonstrado que os cátions $\mathrm{Na}^{+}$e $\mathrm{K}^{+}$podem ser complexados pelos heteroátomos presentes no PEO, bem como outros tipos de polímeros, que doam elétrons livres originando um complexo de sal e formando assim um eletrólito sólido polimérico, chamado de ESP ${ }^{1}$. Visando aplicações práticas desde então foram propostos diversos sistemas poliméricos com condutividade iônica, já que o PEO mostrava problemas devido à fusão da fase cristalina em torno de $60^{\circ} \mathrm{C}$. Além disso, as condutividades iônicas de ordem $10^{-6} \mathrm{~S} / \mathrm{cm}$ eram consideradas baixas. Portanto tendo como objetivo a diminuição da cristalinidade e o aumento da condutividade, foram adotadas modificações tais como enxertias, entrecruzamentos e plastificações usando PEO e outros polímeros tais como PVA, PVC e PVDF ${ }^{2}$. Subseqüentemente, fez-se estudos que envolveram matrizes sólidas, como cerâmicas e géis ${ }^{3}$. Também devido aos problemas ambientais como descarte de lixo e o uso excessivo de petróleo nos últimos anos foram propostos os eletrólitos à base de polímeros naturais por apresentarem propriedades de biodegradação, facilidade de obtenção e baixo custo ${ }^{4}$.

Dentre os polímeros naturais mais estudados foram os polissacarídeos, tais como, hidroxietil celulose ${ }^{5}$, amido ${ }^{6}$, agar ${ }^{7}$, inclusive macromoléculas protéicas como a gelatina ${ }^{8}$. Está última se demonstrou muito promissora como matéria-prima para 
obtenção de membranas transparentes e condutoras iônicas e, portanto foi escolhida para a pesquisa sobre eletrólitos poliméricos para células solares, tema desta dissertação. A grande importância da obtenção de ESPs a partir de produtos naturais é que, os mesmos são facilmente obtidos, possuem baixo custo de produção e são fontes energéticas renováveis. Esse conjunto de características é de grande importância e de grande interesse tecnológico. As membranas à base de gelatina foram obtidas através de plastificação da gelatina com glicerol, entrecruzamento com formaldeído e adição de par iônico Lil//L.

\subsection{Colágeno}

"O colágeno é o tipo de proteína mais abundante nos animais e no corpo humano. Tem função extracelular, forma as estruturas protéicas dos ossos, tendões e peles, além de fazer parte das conexões entre os órgãos do corpo humano." 9 . As macromoléculas de origem animal e vegetal têm a propriedade de se solubilizarem em água e formarem membranas/filmes contínuos e quase sempre transparentes além de serem biodegradáveis. Por isso, atraem atenção especial dos pesquisadores nas diversas áreas científicas. As gelatinas são os primeiros materiais empregados na formação de biomateriais, são produzidas em todo o mundo, possuem baixo custo, não são tóxicas e são biodegradáveis, além de produzirem excelentes filmes ${ }^{9}$.

O colágeno é a proteína que é usualmente aplicada no ramo alimentício, bem como na medicina e indústrias farmacológicas ${ }^{9}$.

O ponto marcante do colágeno é a presença de várias estruturas moleculares, com abundante composição de aminoácidos com 33\% de glicina e $22 \%$ de prolina e sempre mantendo uma boa estrutura quaternária de tripla hélice rígida. Até 1969 acreditou-se que a estrutura era caracterizada por três hélices, com poliprolina, poliglicina e iminoácidos (polihidroxiprolina), que eram altamente espiraladas por resíduos presentes em cada uma delas. Finalmente as mesmas são ligadas entre si e entre cadeias através de ligações de hidrogênio chamadas de tipo I, como é mostrado 
na Figura 1. Após muitas décadas com auxílio de técnicas de difração, considerou-se a possibilidade da presença da unidade repetitiva glicina-prolina-hidroxiprolina, bem como presença de outros aminoácidos, como a arginina, considerada como sendo uma impureza ${ }^{9}$.

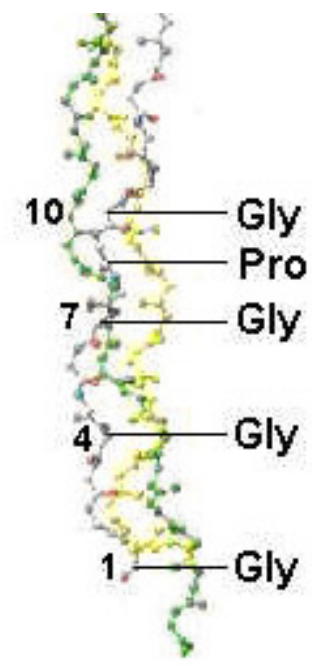

Figura 1 - Estrutura quaternária do colágeno. ${ }^{10}$

\subsection{Gelatinas}

As gelatinas são produzidas a partir de subprodutos obtidos em curtumes (raspas do couro, dos ossos e cascos), são produtos da desnaturação e hidrólise parcial do colágeno. A conversão se baseia na desintegração da estrutura de tripla hélice do colágeno através da quebra das ligações de hidrogênio, sendo assim, a estrutura é quebrada em moléculas de menores pesos moleculares. O processo geral de obtenção da gelatina consiste em três passos: pré-tratamento do material bruto obtido dos subprodutos citados acima, extração da gelatina e purificação (secagem) da mesma. Tais materiais possuem algumas vantagens que são: presença de grupos ácidos e básicos, formação de tripla hélice na estrutura quaternária, solúvel em água e formação de géis. 
Compostos gelatinosos constituem sempre um sistema heterogêneo. O processo de produção das gelatinas é resultado de uma mistura de diversas cadeias, cada uma com respectivos pesos moleculares, composição de aminoácidos e grau de modificação química diferentes ${ }^{11}$.

As gelatinas comerciais são parcialmente ou completamente desaminadas ${ }^{11}$, fato que diminui a capacidade das moléculas formarem hélices estáveis. Ao longo de cada hélice a prolina e a hidroxiprolina não apresentam uma ordem específica na cadeia lateral do aminoácido, bem como densidades de carga (positivas ou negativas) e resíduos polares e apolares locais. Observa-se também que as gelatinas não apresentam estruturas moleculares estáticas, uma vez que acontecem contínuos rearranjos nas moléculas do gel. É difícil prever todos os detalhes envolvidos em escala molecular, portanto, considera-se que os géis são compostos de apenas um tipo de molécula (colágeno desnaturado) ${ }^{11}$.

\subsection{Plastificantes}

Plastificantes são por definição substâncias com massa molecular baixa e interação do tipo primária: ligações iônicas e do tipo secundária: ligação de hidrogênio ou de van der Waals com o polímero, os plastificantes podem aumentar a condutividade iônica e melhorar o contato entre o eletrólito e o eletrodo ${ }^{12}$. Dentre as substâncias plastificantes, pode-se citar o glicerol, o carbonato de etileno (EC) e o carbonato de propileno $(P C){ }^{12}$. Na presença de plastificante os íons são transportados mais rapidamente na fase gelatinosa. Plastificantes também têm a importância no que se diz respeito ao aumento das características amorfas dos ESP ${ }^{13}$.

O glicerol tem sido utilizado devido às três hidroxilas presentes na molécula, fato que proporciona uma boa afinidade com os ESPs devido às ligações de hidrogênio formadas com os grupos funcionais presentes nos polímeros. Segundo Avella e col. ${ }^{13}$, alguns polissacarídeos, como o alginato, liberam água durante o aquecimento, o plastificante evita essa perda por interagir bem com a água. Isso explica a importância 
do glicerol em maior quantidade em massa com relação à matriz, além de atuar na diminuição da temperatura vítrea, $T_{g}$ do eletrólito formado.

O glicerol atua também nas propriedades mecânicas dos ESPs, os pesquisadores J. Gueguen e G. Viroben ${ }^{14}$ relataram que tal plastificante causa uma enorme queda no módulo de elasticidade até a fratura.

A adição de glicerol em amostras com matrizes protéicas promove um aumento no grau de polimerização e considerando a sensitividade desses filmes com relação à água, nota-se que a superfície do eletrólito se torna mais hidrofóbica ${ }^{14}$, fato indicado pelo alto valor do ângulo de contato da gota de água com o ESP. Relata-se inclusive, que a eliminação da água pelo glicerol torna as ligações peptídicas mais fortes ${ }^{14}$.

\subsection{Substâncias reticulantes}

As substâncias reticulantes são moléculas que promovem a interligação de diferentes cadeias poliméricas criando as ligações cruzadas, como no caso da vulcanização da borracha natural. A formação das ligações cruzadas na amostra resulta na alteração das propriedades funcionais, tais como, resistência à temperatura, diminuição da solubilidade e alteração da transparência. No caso da gelatina podem ser usados o formaldeído, o glioxal e a enzima transglutaminase ${ }^{15-17}$.

O aumento da concentração de substâncias reticulantes leva à redução das frações das massas molares dos aminoácidos presentes e conseqüentemente na diminuição da solubilidade dos ESPs devido ao aumento de ligações covalentes presentes na amostra. Conseqüentemente isso leva à redução do volume livre da matriz polimérica ${ }^{18}$.

O formaldeído é o agente reticulante de gelatina mais simples encontrado. Os aldeídos reagem mais rapidamente com as proteínas, a reação ocorre de maneira espontânea e irreversível com os grupos laterais, como tirosina, histidina, triptofano e arginina, formando assim as ligações cruzadas. No caso das gelatinas ele pode reagir com glicina, prolina e hidroxiprolina ${ }^{18}$. Os aldeídos também são utilizados na fabricação 
de filmes fotográficos e micro cápsulas produzidas por coacervação à base de gelatina, entre outras aplicações, onde os mesmos enriquecem as propriedades funcionais dos materiais produzidos.

É importante ressaltar como o formaldeído influi nas propriedades mecânicas dos ESPs, ele aumenta a rigidez e conseqüentemente diminui a capacidade de deformação devido à redução da mobilidade molecular causada pelas ligações cruzadas. Termicamente o formaldeído aumenta a $T_{g}$ do eletrólito. E por fim, atua como barreira, diminuindo a solubilidade do filme.

\subsection{Sais}

Apesar de existirem polímeros com propriedades condutoras tanto iônicas quanto eletrônicas a maioria das moléculas poliméricas possui valores de condutividade relativamente baixos, i.e., na faixa de $10^{-12}$ a $10^{-10} \mathrm{~S}_{\mathrm{cm}}{ }^{-1}$. Porém ao adicionar ao PEO uma pequena quantidade de sal inorgânico que contêm lítio, como por exemplo, $\mathrm{LiClO}_{4}$, ocorre a dissociação do mesmo através da coordenação do lítio com um dos pares elétrons livres do átomo de oxigênio presente na estrutura do polímero. O mesmo pode ser observado para as macromoléculas de gelatina onde após a adição de sal de lítio forma-se um complexo entre o lítio e os grupos funcionais dos aminoácidos (Figura 2). Segundo Vieira e Pawlicka ${ }^{18}$, em comparação a eletrólitos com sais de metais alcalinos, os condutores protônicos possuem melhor dinâmica de transporte iônico e na maioria dos casos os eletrólitos na forma de gel possuem uma matriz polimérica "inchada" com uma solução do próton doador em um solvente polar e sítios redox. 


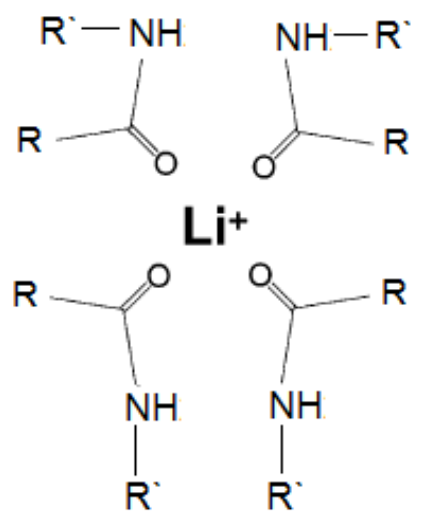

Figura 2 - llustração da forma de coordenação do lítio com o oxigênio presente nos aminoácidos.

Também segundo os mesmos autores, a utilização de $\mathrm{LiBF}_{4}$ em ESP à base de gelatina comercial promoveu uma condutividade iônica de $1,45 \times 10^{-5} \mathrm{~S}_{\mathrm{cm}}{ }^{-1} \mathrm{em}$ temperatura ambiente ${ }^{18}$. Contudo observa-se que a adição dos sais confere um aumento de condutividade até certo limite de concentração do sal após o qual ocorre uma diminuição da mesma. Por causa disso, fatores como grau de dissociação do sal, constante dielétrica do polímero, grau de agregação iônica e a mobilidade das cadeias poliméricas alteram o grau de transporte iônico dentro da matriz polimérica ${ }^{18}$.

Compostos orgânicos também podem contribuir na condutividade dos ESPs, como no caso do ácido acético, que por ser um ácido de base fraca, libera um próton $\left(\mathrm{H}^{+}\right)$, que fica livre para se coordenar com o oxigênio presente. Em outro trabalho Vieira e col. ${ }^{12}$ relataram que a condutividade máxima obtida em ESPs à base de gelatina

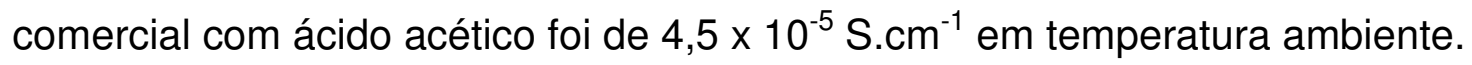

A Tabela 1 mostra algumas características físico-químicas de substâncias que promovem a condutividade iônica.

Tabela 1 - Propriedades físico-químicas de alguns sais e ácido acético ${ }^{32}$.

\begin{tabular}{ccccc}
\hline Agentes lonizantes & $\begin{array}{c}\text { Massa Molar } \\
\left(\mathbf{g} \cdot \mathbf{m o l}^{-1} \mathbf{)}\right.\end{array}$ & $\begin{array}{c}\text { Massa Específica } \\
\left(\mathbf{g} \cdot \mathbf{c m}^{\mathbf{3}} \mathbf{)}\right.\end{array}$ & $\begin{array}{c}\text { Ponto de Fusão } \\
\mathbf{(} \mathbf{C})\end{array}$ & $\begin{array}{c}\text { Solubilidade em } \\
\mathrm{H}_{2} \mathrm{O} \text { a } \mathbf{2 5} \text {-C }\end{array}$ \\
\hline $\mathrm{LiBF}_{4}$ & 93.75 & 0.852 & 275 & Muito Solúvel \\
$\mathrm{Lil}$ & 133.85 & 3.494 & 459 & $151 \mathrm{~g} / 100 \mathrm{~mL}$ \\
$\mathrm{LiClO}_{4}$ & 106.39 & 2.43 & 236 & $60 \mathrm{~g} / 100 \mathrm{~mL}$ \\
$\mathrm{HCl}$ & 36.46 & 1,19 & -114.2 & $72 \mathrm{~g} / 100 \mathrm{~mL}$ \\
$\mathrm{CH}_{3} \mathrm{COOH}$ & 60.05 & 1.049 & 16.5 & Muito Solúvel \\
\hline
\end{tabular}




\subsection{Aplicação de ESPs em Células Solares}

As células solares são dispositivos eletroquímicos que convertem a energia solar em energia elétrica. As mais tradicionais são feitas com silício, contudo, a mais de 20 anos atrás Grätzel ${ }^{19}$ propôs uma nova abordagem, i.e., a utilização de camadas de $\mathrm{TiO}_{2}$ nanocristalinas sensibilizadas por corante (DSSC), que geralmente é um composto de coordenação tendo a bipiridina como ligante. Esta descoberta atraiu a atenção da comunidade científica devido à boa eficiência obtida (em torno de 10,4\%) pela mesma, além do baixo custo e de usar um processo limpo ambientalmente ${ }^{20}$. Apesar, de essa invenção ser interessante, a mesma possui um ponto negativo, que é a utilização de eletrólitos líquidos, que por sua vez introduzem risco de vazamentos ou evaporação dos mesmos ${ }^{20}$. Por causa disso, muitos pesquisadores têm estudado a possibilidade de produzir eletrólitos sólidos ou na forma de géis com objetivo de aplicação nas células do tipo Gratzel.

Freitas e col. ${ }^{20}$ relatam que desde 1996 estudam a produção de eletrólitos sólidos poliméricos baseados em copolímeros de PEO, obtendo-se uma eficiência de conversão de $2.6 \%$. E mais recentemente com a utilização de par redox $I^{3-} \|^{-}$na matriz polimérica, obtiveram eficiência máxima de 3,5\%.

Como mencionado acima, as células do tipo Gratzel usam filmes finos de $\mathrm{TiO}_{2}$ sensibilizadas com corante. A função do corante é a injeção de um elétron a partir de um estado foto-excitado, que geralmente é um composto de coordenação, até a banda de condução do eletrodo que contém nanopartículas de algum tipo de óxido, a presença do eletrólito promoveu a regeneração do corante devido à redução dos cátions presentes no mesmo. Os eletrólitos estudados para este fim são formados então pela adição de $\mathrm{Lil}_{2} 2 \mathrm{H}_{2} \mathrm{O}$ e $\mathrm{I}_{2}$. O sistema apresenta átomos de $\mathrm{Li}^{+}$que se coordenam com os oxigênios das carbonilas presentes na estrutura da gelatina, além de ter um par redox que é o intermediador da regeneração do corante, isso acontece devido à seguinte reação: $\mathrm{I}^{-}+\mathrm{I}_{2}=\mathrm{I}^{3-}$, como $\circ$ Lil.2 $\mathrm{H}_{2} \mathrm{O}$ está em excesso o equilíbrio fica completamente deslocado para a formação do $\mathrm{I}^{3-}$, logo o par redox presente no ESP é o seguinte: $I^{3-} / I^{-}$. 
Para resumir, uma célula solar contém um eletrodo oticamente transparente, sobre qual é depositado $\mathrm{TiO}_{2}$ juntamente com o corante. $\mathrm{O}$ eletrólito, então contendo Lil. $2 \mathrm{H}_{2} \mathrm{O}$ e $\mathrm{I}_{2}$, é depositado por cima e por final, fixa-se todo o sistema com um contra eletrodo. A Figura 3 ilustra a confecção de uma célula solar do tipo Gratzel.

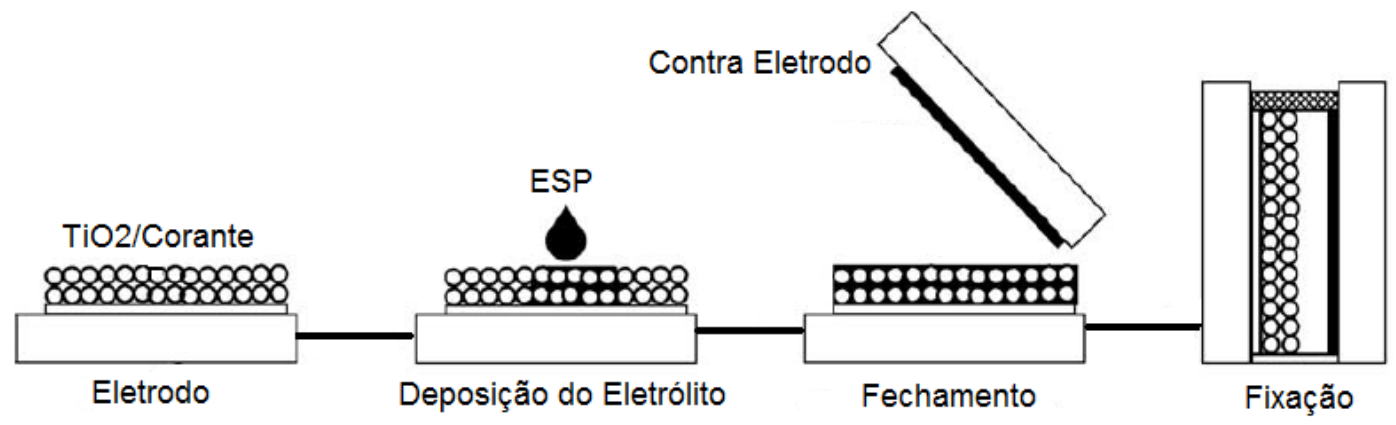

Figura 3 - Esquema de montagem de uma célula solar. ${ }^{21}$

O funcionamento deste tipo de célula solar (Figura 4) consiste em um elétron que é liberado para a banda de condução do $\mathrm{TiO}_{2}$, devido à presença de luz solar que excita o corante presente na estrutura do dispositivo, subseqüentemente o corante catiônico recebe elétrons do par redox $\mathrm{I}^{3-} / \mathrm{I}^{-}$formado. O íon triiodeto recebe um elétron oriundo do contra eletrodo de platina e regenera o íon iodeto. O corante também é regenerado devido ao par redox. Em resumo, essas células são resultantes de uma série de materiais combinados, tais como, eletrodos opticamente transparentes, semicondutor de óxido nanoparticulado, metal complexo inorgânico, eletrólito e corante orgânico ${ }^{20}$.

As reações envolvidas em todo o processo estão demonstradas nas equações abaixo.

$$
\begin{aligned}
& \mathrm{TiO}_{2} \mid \text { Corante }+\mathrm{hv} \rightarrow \mathrm{TiO}_{2} \mid \text { Corante }^{*} \\
& \mathrm{TiO}_{2} \mid \text { Corante }^{*} \rightarrow \mathrm{TiO}_{2} \mid \text { Corante }^{+}+\mathrm{e}^{-} \mathrm{cb} \\
& \mathrm{TiO}_{2} \mid \text { Corante }^{+}+\mathrm{e}_{\mathrm{cb}}^{-} \rightarrow \mathrm{TiO}_{2} \mid \text { Corante } \\
& \mathrm{TiO}_{2} \mid \text { Corante }^{+}+3 / 2 \mathrm{I}^{-} \rightarrow \mathrm{TiO}_{2} \mid \text { Corante }+1 / 2 \mathrm{I}^{3-} \\
& 1 / 2 \mathrm{I}^{3-}+\mathrm{e}^{-}{ }_{(\mathrm{Pt})} \rightarrow 3 / 2 \mathrm{I}^{-} \\
& \mathrm{l}^{3-}+2 \mathrm{e}_{\mathrm{cb}}^{-} \rightarrow 3 \mathrm{I}^{-}
\end{aligned}
$$


Para melhorar a eficiência do dispositivo, cada componente deve ser modificado separadamente. Hoje em dia segundo Freitas e cols. ${ }^{20}$, estudam-se a possibilidade de cada vez mais substituir os componentes da célula solar por materiais plásticos, que quando devidamente modificados combinam as excelentes vantagens de processamento, além das propriedades físicas e mecânicas semelhantes aos metais e semicondutores. Gratzel.

A Figura 4 mostra o processo geral do funcionamento da célula solar do tipo

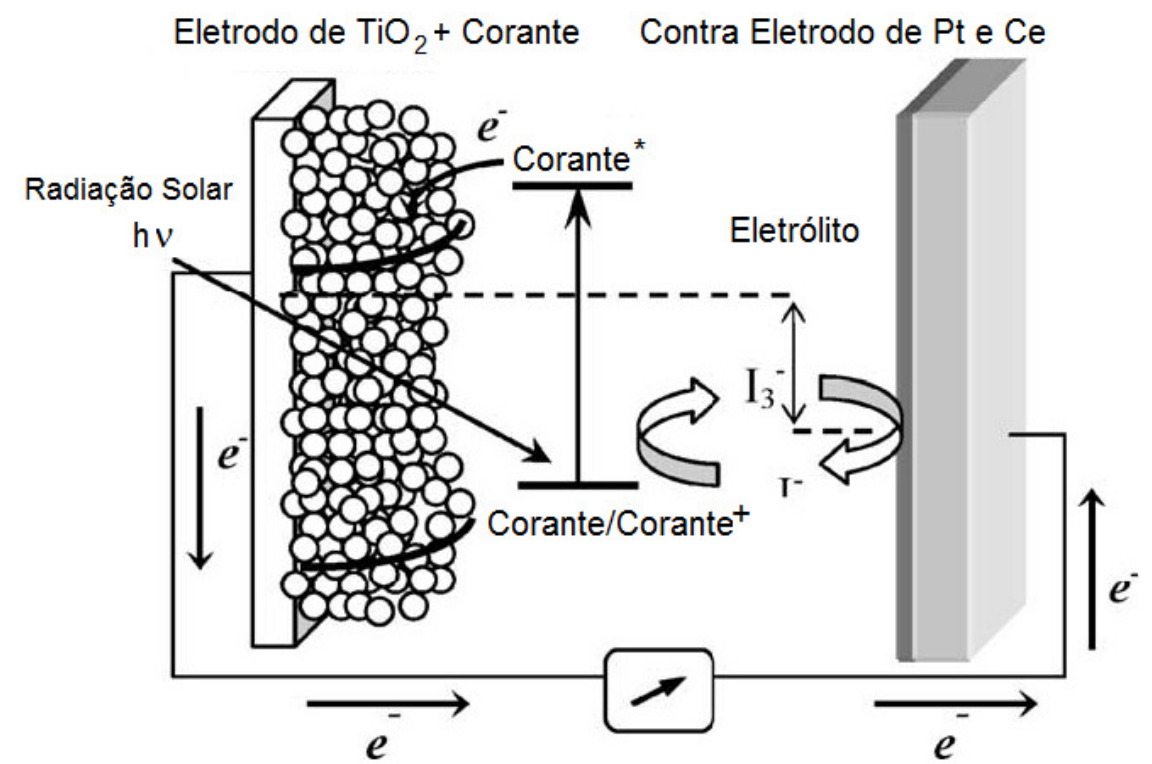

Figura 4 - Representação de funcionamento de uma célula solar do tipo Gratzel (DSSC) com o processo de transferência eletrônica para a conversão de energia solar em energia elétrica. ${ }^{21}$.

Como visto nesta revisão, a adições de par redox, plastificante, agente reticulante à matriz polimérica contribui com o aumento da condutividade do ESP produzido e conseqüentemente isso contribuirá para a obtenção de uma boa eficiência de conversão de energia solar em energia elétrica através de uma DSSC, bem como a utilização de nanopartículas de $\mathrm{TiO}_{2}$ e corante orgânico apropriado. Um dos pontos principais no sucesso deste tipo de célula é a presença do par redox $\mathrm{I}^{3-} / \mathrm{I}^{-}$, que possibilitam a regeneração do corante, isso permite a reutilização da célula durante um tempo significativo ${ }^{21}$. 


\section{OBJETIVOS}

O principal objetivo do presente trabalho foi confeccionar e caracterizar eletrólitos sólidos poliméricos (ESP) à base de gelatina comercial contendo $\mathrm{Lil} / \mathrm{I}_{2}$ para eventual uso em células solares. 


\section{MATERIAIS E MÉTODOS}

\section{Preparação das amostras}

Sob agitação magnética e uma temperatura de $50^{\circ} \mathrm{C}, 2,0 \mathrm{~g}$ de gelatina comercial incolor e sem sabor (Dr. Oetker ${ }^{\circledR}$ ) foi misturada com água Millipore Milli-Q com resistividade controlada de $18 \mathrm{~m}^{-1} \mathrm{~cm}^{-1}$ à $25^{\circ} \mathrm{C}$, até a completa dissolução. Em seguida adicionou-se a mistura, em diferentes quantidades, de $\mathrm{Lil} .2 \mathrm{H}_{2} \mathrm{O} / \mathrm{I}_{2}$ na proporção de $10: 1 \mathrm{~m} / \mathrm{m}$. Em seguida adicionou-se $2,5 \mathrm{~g}$ de glicerol (glicerina) retornando a agitação por mais alguns minutos. Por fim, adicionou-se $0,25 \mathrm{~g}$ de formaldeído. Após o término da agitação colocou-se as misturas em Placas de Petri que foram repousadas em ambiente aberto por 72h. Após isso, as placas foram depositadas em um dessecador por mais $96 \mathrm{~h}$.

Os valores das quantidades de sais com relação a cada amostra estão representados na Tabela 2 .

Tabela 2 - Valores de sal adicionado

\begin{tabular}{cccc}
\hline Amostra & Lil.2 $_{\mathbf{2}} \mathbf{O}(\%)$ & Glicerol (\%) & Formaldeído (\%) \\
\hline Gelatina 1(G1) & 30 & 125 & 12,5 \\
Gelatina 2 (G2) & 35 & 125 & 12,5 \\
Gelatina 3 (G3) & 40 & 125 & 12,5 \\
Gelatina 4 (G4) & 45 & 125 & 12,5 \\
Gelatina 5 (G5) & 50 & 125 & 12,5 \\
\hline
\end{tabular}

Obs: As quantidades de ${ }^{2}$ equivalem a $10 \%$ em massa do $\mathrm{Lil}_{2} 2 \mathrm{H}_{2} \mathrm{O}$ 


\section{Caracterização das amostras}

\subsection{Métodos espectroscópicos de caracterização de ESPs}

A Figura 5 ilustra o espectro eletromagnético.

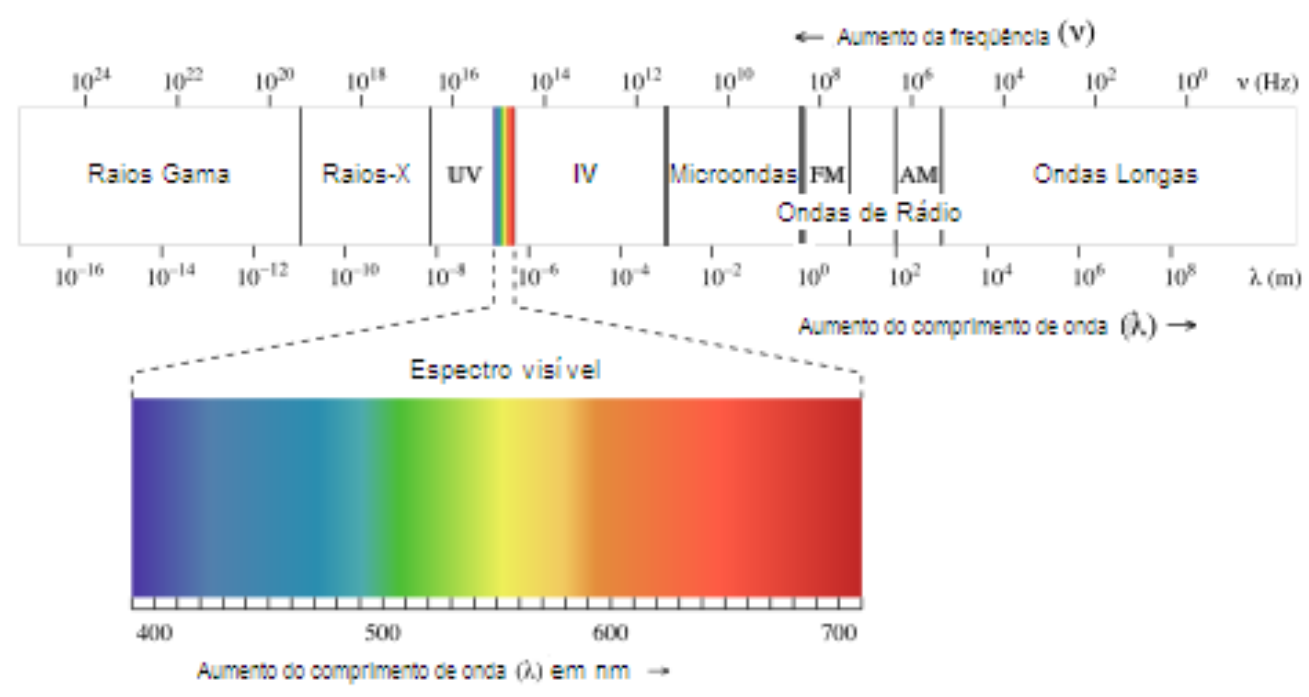

Figura 5 - Espectro eletromagnético. ${ }^{22}$

Os métodos espectroscópicos são classificados de acordo com a região do espectro eletromagnético, tais regiões incluem os Raios Gamma, Raios X, Ultravioleta, Visível, Infravermelho, Microondas e Ondas de Rádio ${ }^{23}$. A radiação eletromagnética é uma forma de energia, que não necessita de matéria para se propagar e é emitida em grandes velocidades. Ela pode ser descrita em termos de comprimento de onda, velocidade, amplitude e freqüência, como mostrado na Figura $6^{23}$. A amplitude A desta onda é determinada pela distância entre a origem do eixo y e a altura máxima da onda; a freqüência é determinada pelo inverso do valor do período, que é a taxa de propagação das ondas no meio; o comprimento de onda é dado como: $\lambda=\mathrm{CV}^{-1}$, onde $\mathrm{c}$ é a velocidade da luz $\left(3 \times 10^{10} \mathrm{~cm} \cdot \mathrm{s}^{-1}\right)$. O comprimento de onda é a distância entre dois 
máximos ou dois mínimos da curva apresentada na Figura 6, que é um gráfico de uma função senoidal. Outro parâmetro que é utilizado para estudar o comportamento das ondas é o número de onda que é igual ao inverso de $\lambda$, que é utilizada na espectroscopia de infravermelho ${ }^{23}$.

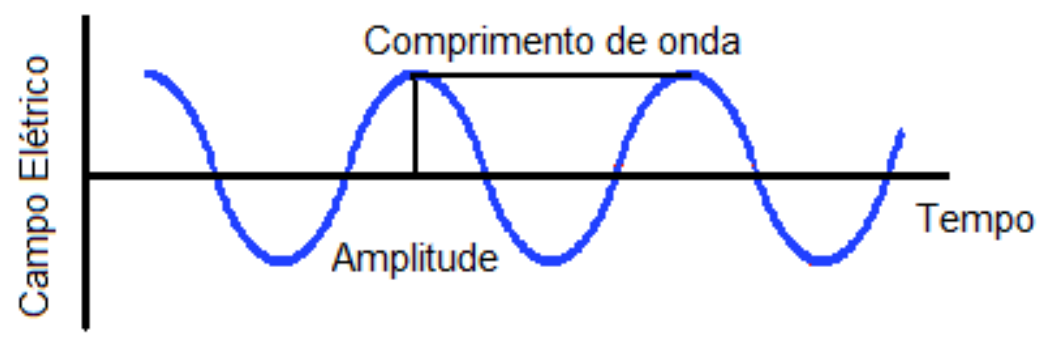

Figura 6 - Comportamento gráfico de uma radiação eletromagnética.

Alguns tipos de interações requerem que a radiação eletromagnética seja considerada como fótons. Os mesmos possuem energia que depende da freqüência da radiação. Segundo Max Planck, um grande colaborador no desenvolvimento da teoria da mecânica quântica a energia pode ser descrita como sendo: $E=h v$, onde h é a constante de Planck $\left(6,63 \times 10^{-34} \mathrm{~J} . \mathrm{s}\right)$. Logo a energia é diretamente proporcional à freqüência e inversamente proporcional ao comprimento de onda ${ }^{23}$. A radiação eletromagnética é considerada como um campo elétrico que passa por oscilações sinuosidais no espaço ${ }^{23}$, como mostrado na Figura 6.

\subsection{1 - Espectroscopia no Ultravioleta e Visível}

Esse método opera entre 190 e $800 \mathrm{~nm}$ do espectro eletromagnético e é baseado em medidas da radiação eletromagnética, que é emitida ou absorvida pela amostra, no caso o eletrólito sólido polimérico. Dependendo da estrutura eletrônica da molécula, ocorre absorção da radiação em comprimentos de onda característicos, sendo assim, ocorre uma atenuação na radiação. Quando ocorre emissão, a amostra é excitada por energias, térmica, radiante ou elétrica ${ }^{23}$. 
Os termos usados em medidas de absorção são: energia radiante, absorbância, transmitância, trajetória do comprimento da radiação, absortividade e absortividade molar $^{23}$.

Quando um feixe (P) atravessa a amostra ocorrem interações entre os fótons e a espécie absorvida, logo o feixe é diminuído de $P_{0}$ a $P$, sendo que a transmitância $(T)$ é definida como a fração da radiação emitida, logo $T=\mathrm{PP}_{0}{ }^{-1}$. $A$ porcentagem de transmitância é um fator muito importante, pois indica a transparência da amostra. A absorbância (A) aumenta conforme os feixes incidentes aumentam de acordo com a seguinte equação: $A=-\log (T)$. Vale ressaltar que a intensidade do feixe cai exponencialmente à medida que atravessa a amostra ${ }^{23}$.

De acordo com a lei de Beer's, a absorbância é linearmente proporcional à concentração (c) da espécie analisada, ao comprimento da radiação (b) e a absortividade (a) que é uma constante de proporcionalidade. Portanto, $\mathrm{A}=\log \left(\mathrm{P}_{0} \mathrm{P}^{-1}\right)=$ $a b c{ }^{23}$.

O espectro de absorção é um gráfico da absorção da amostra (eixo y) versus comprimento de onda (eixo X), como mostrado em um exemplo hipotético na Figura 7.

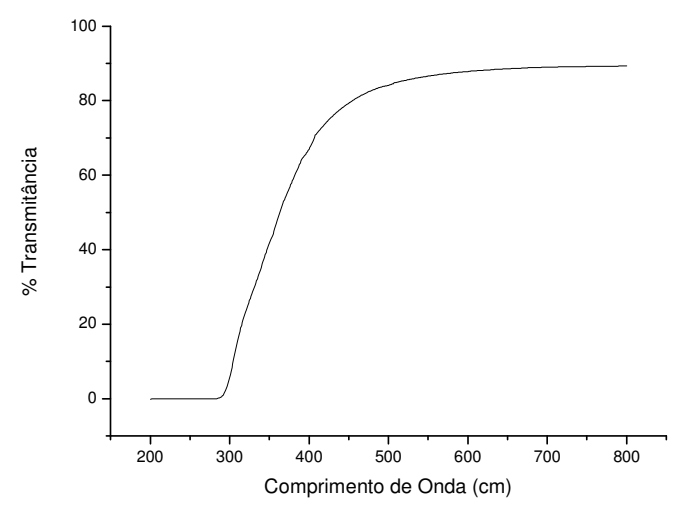

Figura 7 - Espectro no ultravioleta e visível de uma substância hipotética.

A magnitude da energia envolvida no processo é a soma das contribuições eletrônicas, vibracionais e rotacionais das moléculas presentes. Através do ponto máximo do log da absorbância se obtêm a porcentagem de transparência das amostras neste caso os ESPs. 
Para a análise das transparências das amostras utilizou-se o espectrofotômetro Jasco modelo V-630, com varredura de 1000 a 200 ๆm, com 801 pontos e velocidade de $1000 \eta \mathrm{m} \cdot \mathrm{min}^{-1}$. Utilizou-se cubeta de quartzo e comprimento de célula de $10 \eta \mathrm{m}$. Além da presença de uma lâmpada de D/W. Os gráficos da amostra foram obtidos, sendo assim, possível obter a \%T para analisar a transparência das amostras.

\subsubsection{Espectroscopia de Impedância Eletroquímica.}

Através da utilização da técnica de espectroscopia de impedância eletroquímica (EIE), que utiliza corrente alternada, os processos eletroquímicos envolvidos em diversos sistemas tornaram-se mais claros e acessíveis ${ }^{24}$. Informações cinéticas e mecânicas podem ser obtidas através da EIE e tal método oferece as seguintes vantagens:

1 - Em corrente alternada usa-se amplitude de excitações muito pequenas, causando perturbações mínimas no sistema e minimizando os erros envolvidos.

2 - Os experimentos em corrente alternada podem produzir dados sobre a capacitância da dupla camada e a cinética de transferência de cargas.

3 - As medidas podem ser realizadas em materiais que possuam baixas condutividades.

Em circuitos de corrente alternada a resistência é obtida em função da freqüência; em corrente contínua os valores de freqüência é zero, logo a obtenção do valor da resistência é obtido através da lei de Ohm: $E=I R^{24}$, onde o I é corrente e $R$ é a resistência.

Em corrente alternada tem-se a expressão semelhante: $E=I Z$, onde $Z$ é a impedância, que tem como significado a obstrução ao fluxo de elétrons. Para relacionar o fluxo de corrente ao potencial, requer-se a obtenção da razão entre $V_{\max } / I_{\max }$, que 
representa a oposição ao fluxo de carga e a obtenção do ângulo $\theta$, que é a diferença de fase entre I e $\mathrm{V}{ }^{24}$. "Na análise numérica da impedância é mais conveniente utilizar eixos cartesianos, onde y é definido como imaginário l" e x como real l', o vetor gerado de corrente alternada é definido como a soma dos componentes real e imaginário: $I$ I l' + I" 24 . A Figura 8 mostra o vetor em termos das coordenadas real e imaginária.

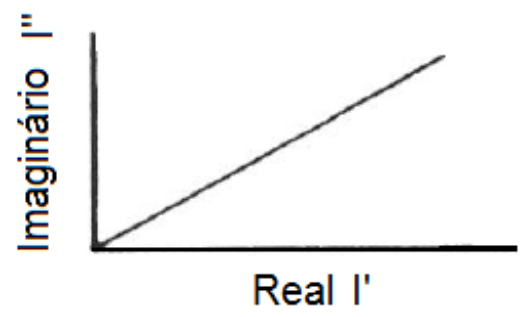

Figura 8 - Análise numérica utilizando eixos imaginário e real. ${ }^{24}$.

Os componentes do gráfico de uma onda de corrente alternada são definidos a partir de uma referência. A componente real está em fase com a referência e a imaginária a $90^{\circ}$ fora da fase. Portanto pode-se calcular o vetor impedância total a partir da divisão dos vetores voltagem e corrente. Logo o vetor resultante para a impedância de corrente alternada é dado como: $Z=Z$ " $+Z$ '. A magnitude do vetor pode ser obtida a partir do módulo de $Z$, e a tangente do ângulo de fase se obtém através do quociente entre Z" e Z' respectivamente ${ }^{24}$.

Esses dados podem ser computados em diversas freqüências aplicadas. Sendo assim, plota-se diversos tipos de curvas de acordo com os tipos de informações desejadas $^{25}$.

O gráfico utilizado para analisar a condutividade dos ESPs é do tipo Nyquist, onde se observa um semicírculo em altas freqüências e uma reta em médias e baixas freqüências ${ }^{25}$, como visualizado na Figura 9. 


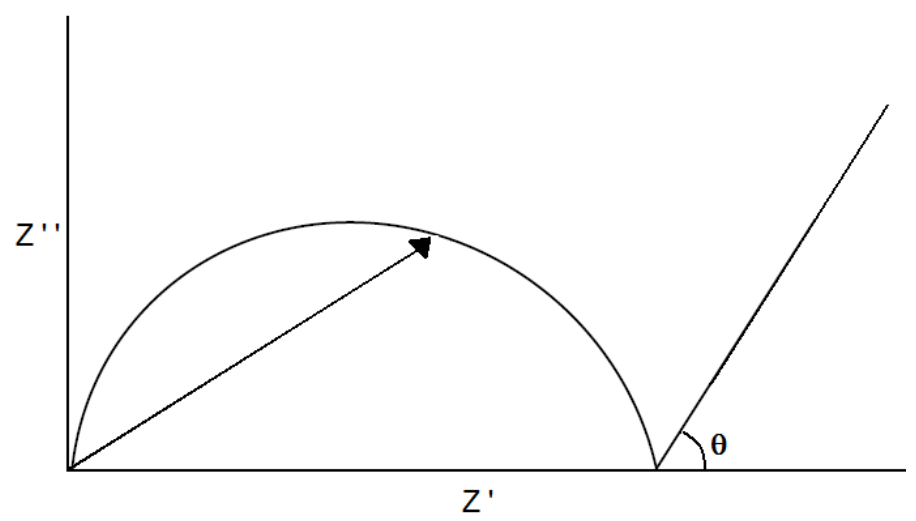

Figura 9 - Comportamento ideal do gráfico de Nyquirst.

A impedância é representada por pontos, em diferentes freqüências, sobre a curva representada na Figura 9. A distância entre a origem e um ponto é a magnitude da impedância em uma determinada freqüência e o ângulo formado entre a reta e o eixo $x$ corresponde à diferença de fase entre a corrente e a voltagem ${ }^{25}$.

Os ESPs têm seus valores de condutividade $(\boldsymbol{\sigma})$ obtidos através da seguinte equação: $\sigma=L(R A)^{-1}$, onde $L$ é a espessura da amostra em $\mathrm{cm}$, $R$ é a parte real da impedância e A é a área do eletrólito em $\mathrm{cm}^{225}$.

Obtêm-se valores de condutividade do ESP em diversas temperaturas, para que possa ser determinado o modelo de condutividade, Arrhenius ou Vogel-TammanFulcher (VTF). $O$ primeiro se caracteriza por uma linha reta do logaritmo da condutividade em função do inverso da temperatura e pode ser explicado em termos da movimentação dos íons, que não resulta do compartilhamento do movimento da matriz polimérica. No segundo caso, observa-se um comportamento exponencial do logaritmo da condutividade em função do inverso da temperatura, explicado em termos da movimentação dos íons, que é compartilhada com o movimento da matriz polimérica ${ }^{26}$.

Para a medida de condutividade utilizou-se o impedancímetro SOLARTRON SI 1260 Impedance/Gain Phase Analyser. Os valores de condutividade foram obtidos para as seguintes temperaturas, além da temperatura ambiente: $30^{\circ} \mathrm{C}, 40^{\circ} \mathrm{C}, 50^{\circ} \mathrm{C}, 60^{\circ} \mathrm{C}$, $70^{\circ} \mathrm{C}$ e $80^{\circ} \mathrm{C}$. Logo, plotou-se gráficos de logaritmo da condutividade versus inverso da 
temperatura. Utilizou-se uma célula de Teflon fechada a baixa pressão. A temperatura é monitorada com o auxílio de um termopar e o forno utilizado foi um EDG \%P.

\subsubsection{Raios X}

Os métodos analíticos que envolvem o uso dos raios $X$ são os seguintes:

1 - Absorção de raios que fornece informações a respeito da concentração e da espessura da amostra.

1 - Fluorescência de raios que é uma ferramenta importante na determinação da composição química dos materiais.

2 - Difração de raios que fornece informações sobre a cristalinidade e a fração cristalina do material.

A geração de Raios $X$ acontece devido ao bombardeamento, sofrido por uma fonte de elétrons com grande energia, subseqüentemente os elétrons provocam a emissão de fótons de radiação $X{ }^{27}$. As fontes geradoras de Raios $X$ mais comuns são: cobre, molibdênio, cobalto e cromo, que também atuam como monocromadores de feixes.

As técnicas que usam Raios $X$ exigem que a radiação seja monocromática através da utilização de monocromadores citados acima. $O$ funcionamento da técnica segue a lei de Bragg: $n \lambda=2 d$.sen $(\theta)$, onde $n$ corresponde à ordem de difração, $\theta$ ao ângulo de difração e $\lambda$ ao comprimento de onda. A Figura 10 mostra a atenuação de um monocromador de radiação, onde os pontos representam a rede cristalina do material. 


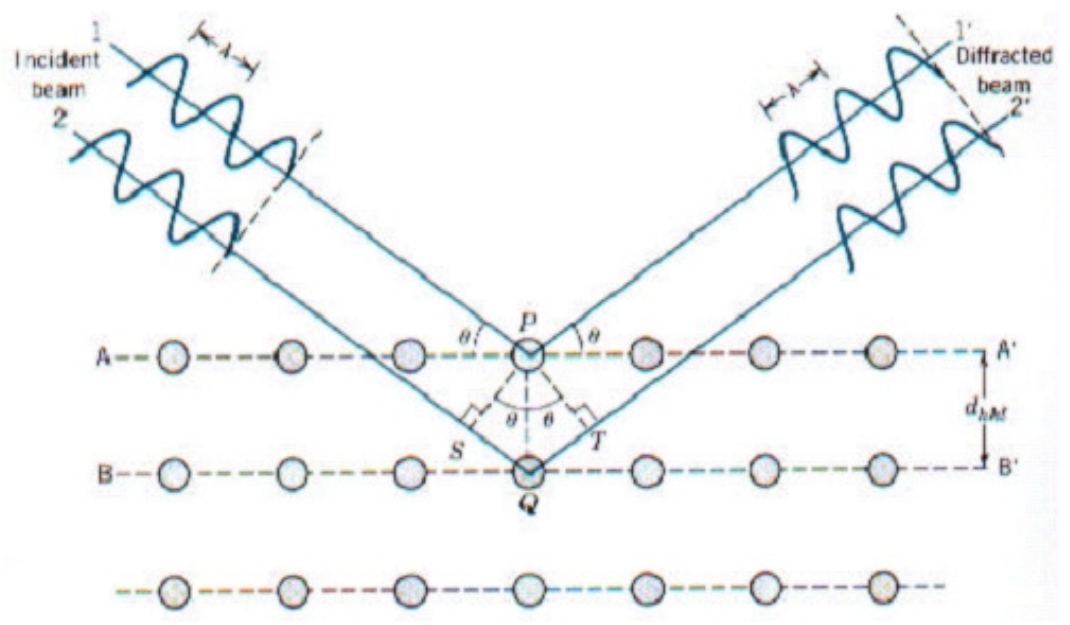

Figura 10 - Demonstração da difração de Raios X, num material. ${ }^{28}$

Materiais poliméricos têm pouca tendência a se cristalizarem completamente devido à complexidade das moléculas presentes nos mesmos, contudo é comum a formação de cristalitos ${ }^{27}$, dependendo das condições de solidificação do material polimérico. Pontos cristalinos podem ocorrer devido às forças mecânicas levando à formação de lamelas (parte cristalina), contudo mais comumente ocorre a formação de esferulitos ${ }^{27}$ quando se solidifica a partir do material fundido.

A cristalinidade é um fator importante, pois define propriedades químicas e físicas do material, bem como a distribuição molecular. Dentre os métodos citados anteriormente, o mais comumente usado é a difração de Raios X, para se determinar tais características. "Os métodos para determinação de cristalinidade podem ser aplicados utilizando-se apenas a relação entre as áreas dos espalhamentos amorfos e cristalinos, ou podem utilizar referências ditas externas" ${ }^{27}$. Tais referências podem ser tanto um material puramente cristalino ou puramente amorfo. A Figura 11 mostra um difratograma de um material essencialmente cristalino, onde se pode perceber que pela lei de Bragg os picos de cristalinidade se apresentam bem definidos. 


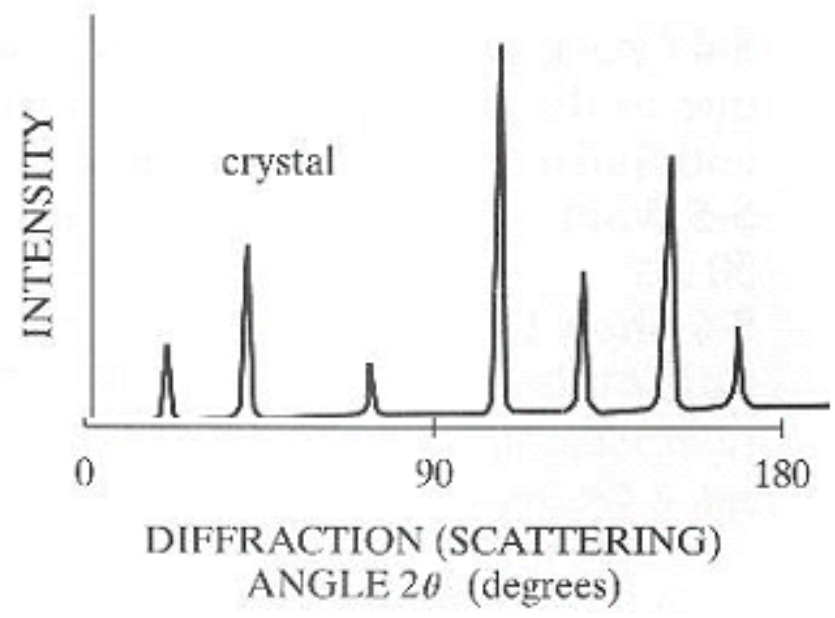

Figura 11 - Difratograma de um material cristalino ${ }^{28}$.

No caso dos eletrólitos o ideal é que os difratogramas mostrem uma região predominantemente amorfa, embora o agente reticulante forneça uma contribuição para que a cristalinidade do ESP aumente. A difração de Raios $X$ tem grande importância para analisar a presença de sal inorgânico não dissolvido na amostra, o mesmo que é preterido ao eletrólito por diminuir a condutividade do mesmo. A Figura 12 mostra um difratograma de um material amorfo.

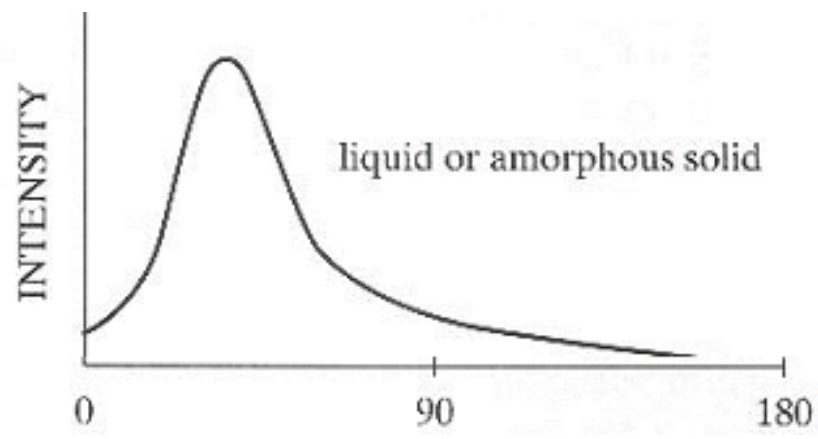

Figura 12 - Difratograma de um material amorfo. ${ }^{28}$.

Os difratogramas foram obtidos com Difratômetro Universal de Raios-X URD-6, CARL ZEISS JENA, a potência $m=40 \mathrm{KV} / 100 \mathrm{~mA}$ e $\mathrm{I}(\mathrm{CuK} \alpha)=1540 \AA$, em um intervalo de ângulo de 5 - $40^{\circ}(2 \theta)$ sobre os filmes à temperatura ambiente. Sendo assim possível observar eventual cristalinidade dos ESPs. 


\subsubsection{Espectroscopia de Absorção no Infravermelho}

A espectroscopia de absorção no infravermelho permite observar as vibrações moleculares, sendo elas basicamente do tipo estiramento e deformação. A Figura 13 ilustra esses dois tipos de vibrações possíveis na molécula.

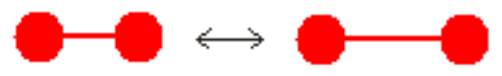

deformaçẫo axial AB

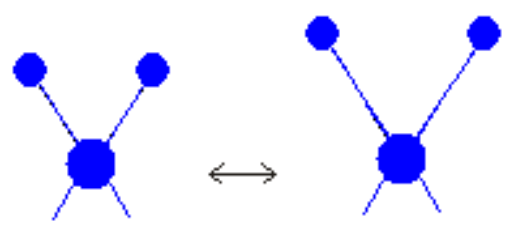

estiramento simétrico $\mathrm{AB}_{2}$

Figura 13 - Dois tipos de vibrações das moléculas.

Os estudos no infravermelho, em grande maioria, são feitos na região média, onde as freqüências vibracionais fundamentais são encontradas, que correspondem ao nível fundamental com $v=0$, onde $v$ é um número quântico que é representado por números naturais $0,1,2,3 \ldots$, e o primeiro nível vibracional excitado com $v=1^{27}$.

Normalmente a posição da banda gerada no espectro é referida em número de onda $\left(\mathrm{cm}^{-1}\right)$. "As freqüências vibracionais dependem da natureza do movimento, massa dos átomos, geometria da molécula, natureza das ligações químicas e ambiente químico/físico" ${ }^{27}$.

O espectrômetro utilizado na caracterização dos eletrólitos foi com transformada de Fourier, que é constituído por uma fonte de radiação, interferômetro, compartimento da amostra e um detector, como mostrado na Figura 14. 


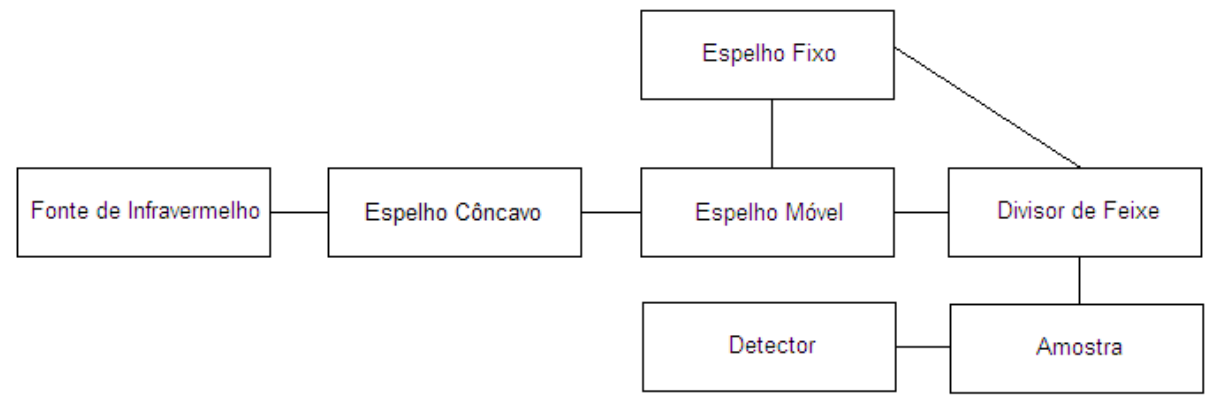

Figura 14 - Esquema de um espectrômetro de infravermelho com transformada de Fourier.

Por utilizar o interferômetro de Michelson, esse tipo de técnica é mais rápida, acessível, precisa e reprodutiva, pois o mesmo possui laser de diodo como fonte de luz e divisor de feixe que consiste em uma lâmina espessa de vidro ou acrílico.

O funcionamento do espectrômetro consiste num feixe que incide em um espelho côncavo, sendo assim, convertido em raios paralelos e dirigidos a um divisor de feixe posicionado a $45^{\circ}$ de incidência, o mesmo divide o feixe em duas partes equivalentes, uma delas é refletida em direção ao espelho fixo e a outra incidida paralelamente em direção ao espelho móvel. A radiação dirigida ao espelho fixo é totalmente refletida voltando ao divisor de feixe, onde metade é refletida em direção à fonte da radiação infravermelha ${ }^{27}$.

Esse tipo de espectroscopia é chamada de "método dos grupos funcionais", ou seja, a partir das bandas obtidas, detecta se grupos orgânicos compostos por carbono, e hidrogênio e/ou heteroâtomos, além de ligações duplas e triplas estão presentes na molécula analisada. Desta maneira no espectro pode se observar grupos tais como: carbonila, carboxila, aminas, metileno e metino entre outros. Na Figura 15 está ilustrado um espectro de infravermelho por transmissão de uma substância orgânica não identificada. 


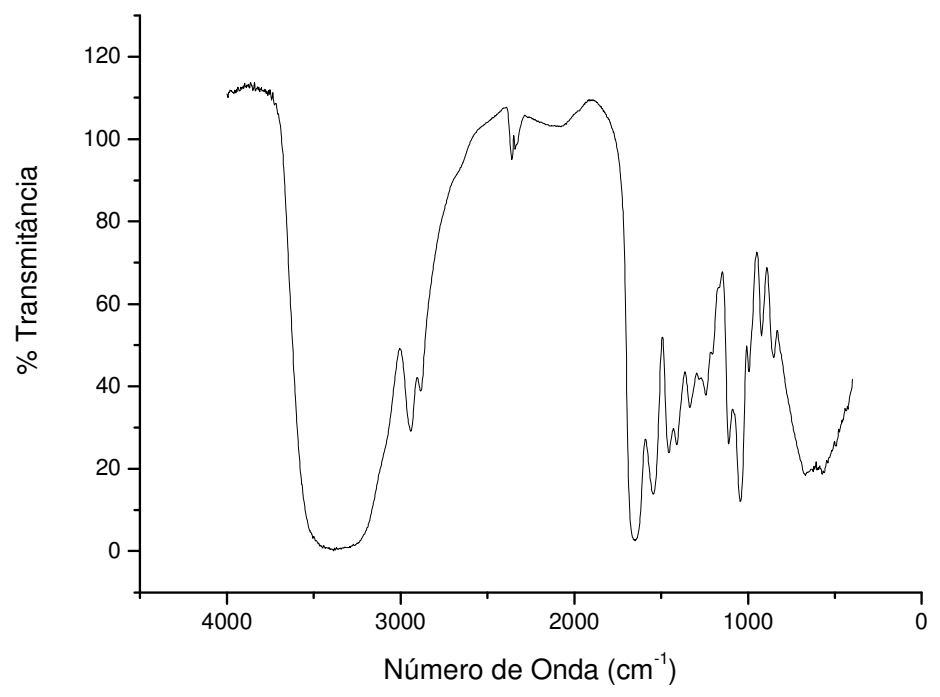

Figura 15 - Espectro de infravermelho de uma substância orgânica não identificada.

O grupo funcional mais importante para o presente trabalho é a hidroxila, que foi analisada qualitativamente na etapa onde se determinou a melhor quantidade de glicerol para o eletrólito. A Figura 16 exemplifica uma banda característica de hidroxila, que se encontra na região entre 3500 e $3400 \mathrm{~cm}^{-1}$.

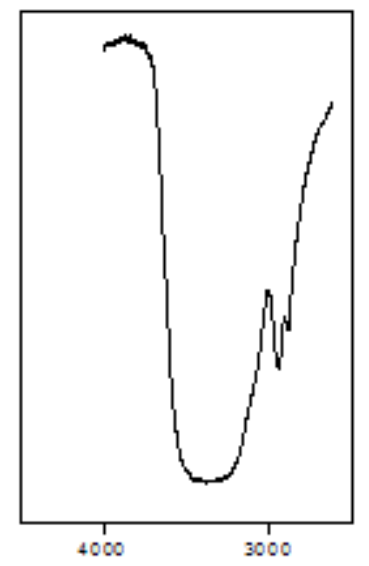

Figura 16 - Banda correspondente à hidroxila presente em uma substância orgânica.

As análises espectroscópicas no infravermelho foram realizadas com o auxílio de um espectrofotômetro Bomem modelo MB-102. Os ESPs, ainda na forma líquida, foram depositados nos discos de silício e secos com o auxílio de um secador. A resolução do 
aparelho foi de $4 \mathrm{~cm}^{-1} \mathrm{com}$ um número de varreduras de 16 na região de 4000 a 400 $\mathrm{cm}^{-1}$.

\subsection{Método térmico para a caracterização de ESPs}

\subsubsection{Calorimetria Exploratória Diferencial}

A calorimetria exploratória diferencial (DSC) é dividida em dois grupos: DSC de fluxo de calor e DSC de compensação de potência ${ }^{27}$.

O DSC de fluxo de calor é uma técnica que se deriva da análise térmica diferencial (DTA), na qual a diferença de temperatura entre uma determinada substância e um material inerte é aferida em função da própria temperatura ${ }^{27}$. Neste método de DSC, amostra e referência são colocadas em cápsulas idênticas, as mesmas são postas em um disco termoelétrico para aquecimento. O fluxo de calor é monitorado por termopares inseridos no disco. "A variação de temperatura $(\Delta \mathrm{T})$ é proporcional à variação de entalpia $(\Delta \mathrm{H})$, à capacidade calorífica e à resistência térmica total ao fluxo calórico" 27.

No modo de compensação de potência um calorímetro é o responsável pela medida da energia térmica. Amostra e referência são aquecidas em fornos separados, se alguma variação na temperatura ocorrer entre eles, os termopares detectam as diferença de temperatura, logo o equipamento modifica a potência de entrada de um forno para igualar as temperaturas. Assim o dH/dT é registrada em função de $T$ ou $t^{27}$.

Deve-se conhecer as linhas de base das curvas geradas pelo equipamento, que é obtida fazendo análise de um branco e deve ser paralela ao eixo $X$, i.e., a temperatura.

Os eventos térmicos que são explicitados em curvas de DSC são de primeira (variações de entalpia) e segunda (variação da capacidade calorífica $\Delta C_{p}$ ) ordem. Eventos endotérmicos observados em polímeros são: fusão, perda de massa, 
dessorção e redução. Eventos exotérmicos são: cristalização, reações de polimerização, cura, oxidação e adsorção. Em uma curva de DSC observa-se formação de picos (positivos ou negativos) para variação de entalpia e deslocamentos na linha de base em forma de s para variação da capacidade calorífica, como uma transição vítrea 27. A Figura 17 mostra um exemplo de uma curva de DSC.

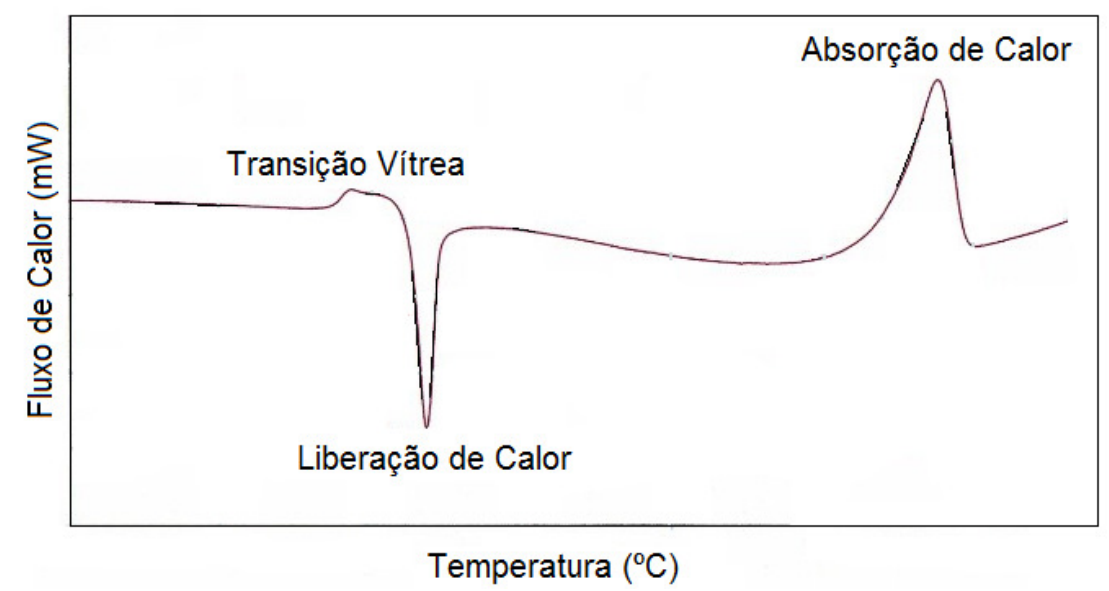

Figura 17 - Exemplo de uma curva DSC com as transições características.

As condições experimentais requerem uma pequena quantidade de amostra ( $1 \mathrm{a}$ $10 \mathrm{mg}$ ) colocada em cadinho de alumínio com tampa hermética ou perfurada. A temperatura deve variar de 25 a $350^{\circ} \mathrm{C}$ com uma taxa de aquecimento de 10 ou $20^{\circ} \mathrm{C} / \mathrm{min}$. A atmosfera deve ser de gás inerte $\left(\mathrm{N}_{2}\right)$. Após a análise se deve subtrair a curva em branco da amostra ${ }^{27}$.

Uma transição importante que ocorre em polímeros é a transição vítrea $\left(T_{g}\right)$, na qual se iniciam os movimentos de segmentos da cadeia polimérica. Essa transição de um estado menos ordenado para um mais ordenado é de segunda ordem, ou seja, ocorre $\Delta \mathrm{C}_{\mathrm{p}}$ na amostra. A Figura 18 explicita a ocorrência da $T_{g}$ e da temperatura de fusão. 


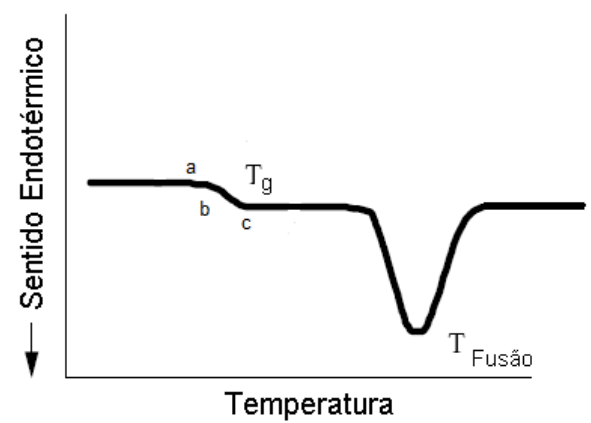

Figura 18 - Exemplo para determinar a $T_{g}$.

Portanto, a $T_{g}$ está contida entre os pontos a e c da curva da Figura 18, quando apenas uma temperatura é citada, geralmente se refere ao ponto b que equivale à metade de $\Delta \mathrm{C}_{\mathrm{p}}{ }^{27}$.

O equipamento utilizado foi o DSC-Q100 da TA Instruments, com a utilização de cadinho de alumínio. As condições das analises térmicas foram: corrida inicial em T ambiente até $140{ }^{\circ} \mathrm{C}$ a $20^{\circ} \mathrm{C} \cdot \mathrm{min}^{-1}$, resfriamento até $-100 .{ }^{\circ} \mathrm{C}$ e subseqüentemente aquecimento até $120^{\circ} \mathrm{C}$ a $10^{\circ} \mathrm{C} \cdot \mathrm{min}^{-1} \mathrm{com}$ fluxo de $50 \mathrm{~mL} \cdot \mathrm{min}^{-1}$ de $\mathrm{N}_{2}$ e com massa de amostra de aproximadamente $20 \mathrm{mg}$.

\subsection{Métodos eletrônicos para a caracterização de ESPs}

\subsubsection{Microscopia Eletrônica de Varredura.}

O principal desafio da microscopia foi conseguir ultrapassar a resolução da luz visível. A microscopia eletrônica de varredura (MEV) está entre as principais ferramentas para estudar a morfologia dos materiais, entre eles polímeros ${ }^{27}$.

Os microscópios eletrônicos utilizam fontes de elétrons como o $\mathrm{LaB}_{6}$. Uma grande vantagem desses microscópios frente aos óticos é que possuem melhor resolução, ou seja, dois pontos próximos na mesma amostra podem ser melhores visualizados, esses tipos de microscópios resolvem detalhes menores e 1 nanômetro ${ }^{27}$. 
O funcionamento da técnica se baseia no fato dos elétrons primários emitidos pela fonte atingirem a amostra e os mesmos elétrons escapando formam a imagem. Existem dois tipos de interações entre elétrons e a matéria: espalhamentos elásticos e inelásticos.

"O espalhamento elástico, também conhecido como espalhamento de Rutherford, é definido como um processo que pode afetar a trajetória do elétron, sem, entretanto, alterar a trajetória do mesmo" ${ }^{27}$. As interações eletroestáticas entre o feixe e o núcleo de um átomo são responsáveis pelo espalhamento e retroespalhamento gerando um sinal em MEV que forma as imagens ${ }^{27}$.

No espalhamento inelástico, ocorre perda de energia dos elétrons que foram incididos, bem como a mudança da trajetória dos mesmos, essas perdas podem ser transferidas para elétrons presentes na amostra. Com a formação de elétrons secundários, permite-se a construção de um tipo de imagem que é a mais comum do MEV.

"A coluna do microscópio consiste de uma fonte de elétrons, lentes magnéticas e bobinas de varredura, operando sob vácuo. O diâmetro do feixe produzido diretamente pela fonte de elétrons convencional é muito grande para gerar uma imagem definida em alta ampliação. As lentes eletromagnéticas, em conjunto com os diafragmas, são usados para reduzir o diâmetro do feixe e focalizá-los sobre a superfície da amostra. As bobinas de varredura têm a função de defletir o feixe e controlar a varredura sobre a superfície da amostra" ${ }^{27}$. Logo a imagem é formada coletando-se um sinal em função da posição do feixe sobre a amostra. A Figura 19 ilustra os componentes do microscópio. 


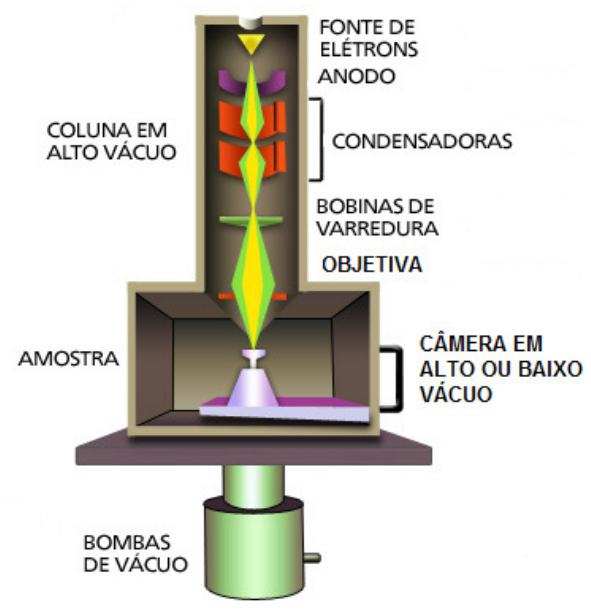

Figura 19 - Componentes de um microscópio eletrônico de varredura. ${ }^{29}$

A irradiação da amostra com os elétrons provoca a emissão de elétrons secundários e retroespalhados, que são os responsáveis pela obtenção das imagens para estudos morfológicos dos materiais. A Figura 20 mostra uma imagem obtida utilizando um microscópio eletrônico de varredura.

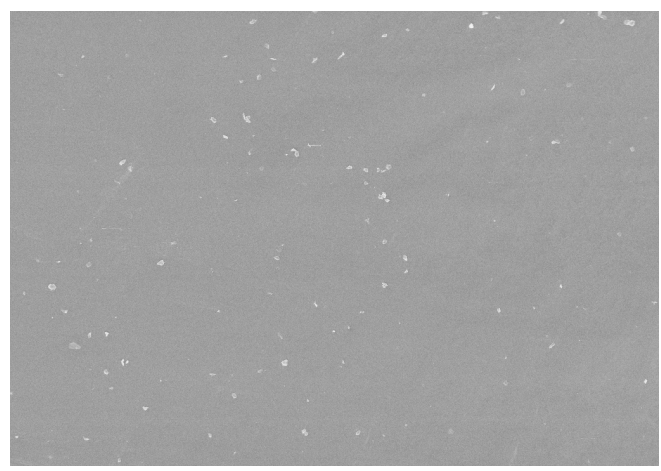

Figura 20 - Micrografia eletrônica de varredura de um ESP.

Vale relembrar, que o que se vê na figura é uma imagem de elétrons secundários, que permitem a caracterização morfológica e topográfica das superfícies das amostras.

As amostras dos eletrólitos poliméricos foram colocados sobre uma fita adesiva de carbono, no porta-amostra de alumínio e recobertas com ouro, com espessura de recobrimento de $20 \mathrm{~nm}$. A corrente do feixe utilizado foi de $1 \mathrm{pA}$ e a potência do feixe de $20 \mathrm{KV}$. 


\subsubsection{Voltametria de Varredura Simples}

"A voltametria é uma técnica eletroquímica onde as informações qualitativas e quantitativas de uma espécie química são obtidas a partir do registro de curvas corrente-potencial, feitas durante a eletrólise dessa espécie em uma célula eletroquímica constituída de pelo menos dois eletrodos, sendo um deles um microeletrodo (o eletrodo de trabalho) e o outro um eletrodo de superfície relativamente grande (usualmente um eletrodo de referência). O potencial é aplicado entre os dois eletrodos em forma de varredura, isto é, variando-o a uma velocidade constante em função do tempo. O potencial e a corrente resultante são registrados simultaneamente. A curva I x. V obtida é chamada de voltamograma" ${ }^{30}$.

As células eletroquímicas utilizadas podem ter dois ou três tipos de eletrodo, no primeiro caso existe um eletrodo de trabalho e um eletrodo de referência. No caso do sistema com dois eletrodos podem acontecer limitações, em alguns casos, como aumento de corrente que passa através dos mesmos, devido às reações ocorridas no eletrodo de referência, isso afeta o voltamograma causando distorções. Para resolver esse tipo de limitação, desenvolveu-se um terceiro tipo de eletrodo, o auxiliar, para assegurar o sistema potenciostático, fazendo com que a resistência do eletrodo de referência aumente, uma vez que deve manter o potencial constante ${ }^{30}$. A Figura 21 mostra uma célula com três eletrodos. 


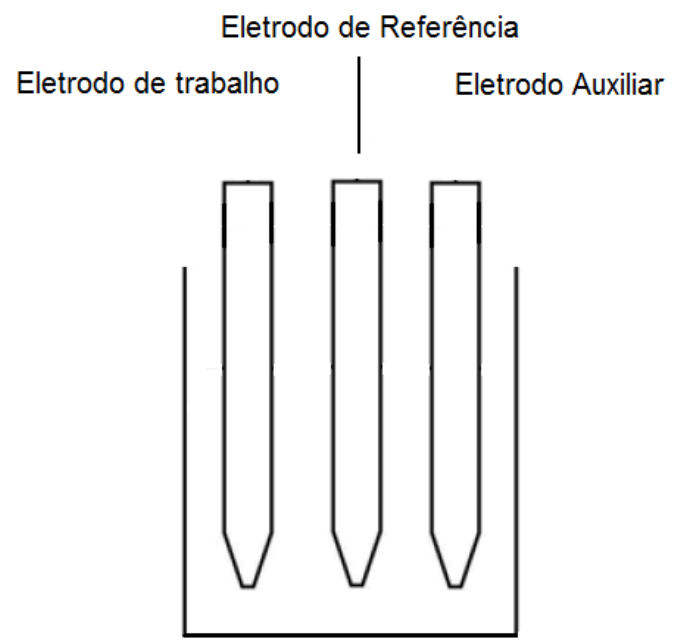

Figura 21 - Célula eletroquímica com três eletrodos.

Nesse tipo de técnica para células solares, utiliza-se uma varredura simples de potencial de 0 a geralmente $-0,9 \mathrm{~V}$. Utiliza-se uma célula se camada fina, onde o ESP é posto em forma de sanduíche preso por dois eletrodos com auxílio de um adesivo. $O$ sistema é submetido a uma luz de grande intensidade, e através das reações de oxirredução o sistema gera informações a respeito da eficiência do sistema. Um gráfico I $x$ V (corrente $x$ potencial) é gerado para fornecer informações a respeito do comportamento da célula ${ }^{31}$. A Figura 22 mostra um exemplo de um gráfico com comportamento ideal para esse tipo de experimento.

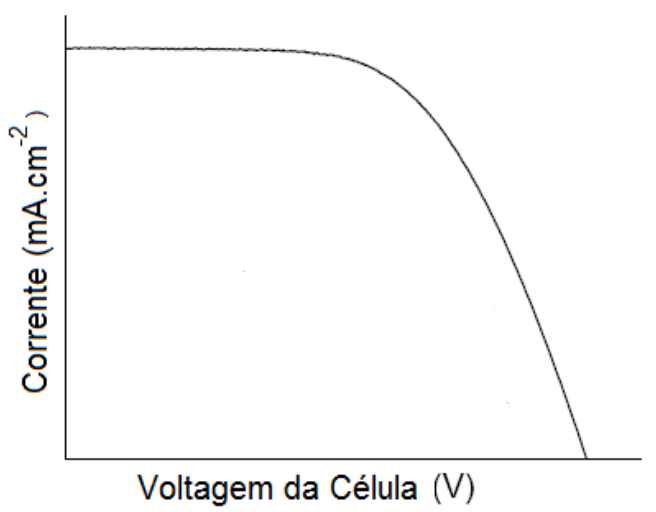

Figura 22 - Comportamento ideal apresentado pela célula solar.

Os filmes utilizados foram de $\mathrm{TiO}_{2}$, a partir de uma solução coloidal espalhada pelo método doctor blading em um vidro recoberto com um substrato transparente condutor FTO (Hartford) usando fita adesiva (Scoth Magic Tape 3M) de espessura de 
$50 \mu \mathrm{m}$ como espaçador. A solução coloidal foi preparada utilizando-se $3,0 \mathrm{~g}$ de $\mathrm{TiO}_{2}$ P25 (Degussa), 1,2062 g de PEG 20000, 5,0 mL de água, 0,1 mL de acetilacetona e $0,05 \mathrm{~mL}$ de Triton-X100 misturados levemente em um cadinho até a obtenção de uma pasta. Após a secagem, os filmes foram submetidos a tratamento térmico de $350{ }^{\circ} \mathrm{C}$ por 10 minutos e $450{ }^{\circ} \mathrm{C}$ por 30 minutos com velocidade de aquecimento de $10^{\circ} \mathrm{C} \cdot \mathrm{min}^{-1} \mathrm{em}$ um forno (EDG3P - S da EDG). As determinações das espessuras destes filmes foram feitas em um equipamento da marca Alpha-Step, obtendo-se uma espessura de $7 \mu \mathrm{m}$.

Após o tratamento térmico, os filmes foram imersos em uma solução $1,5 \times 10^{-4} \mathrm{~mol} \mathrm{~L}^{-1}$ de ftalocianina de cobre, com concentração de $972,79 \mathrm{~g} \mathrm{~mol}^{-1} \mathrm{da}$ Aldrich, em acetonitrila por 20 horas. Posteriormente, os eletrodos foram lavados com acetonitrila e deixados em atmosfera ambiente por um tempo de 5 minutos para a evaporação do solvente. A Figura 23 mostra a estrutura química do corante.

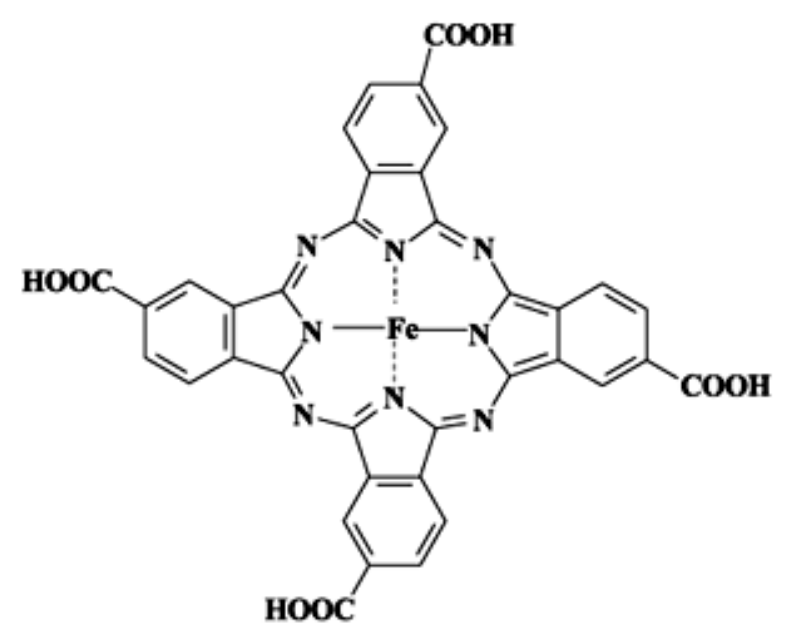

Figura 23 - Estrutura molecular da ftalocianina de ferro tetracarboxilada.

Os filmes de platina foram preparados por deposição de uma alíquota de uma solução de $5,0 \times 10^{-2} \mathrm{~mol} \mathrm{~L}^{-1}$ de $\mathrm{H}_{2} \mathrm{PtCl}_{6}$ em isopropanol sobre $\mathrm{FTO}$, seguido de tratamento térmico a $350{ }^{\circ} \mathrm{C}$ por 20 minutos.

A célula foi montada em laboratórios da $\operatorname{Prof}^{\mathrm{a}}$. Dr ${ }^{\mathrm{a}}$. Ana Flávia Nogueira do IQUNICAMP com a ajudo do seu aluno Flávio Santos Freitas em forma de "sanduíche" com o contra-eletrodo transparente de platina utilizando filme de PVC como espaçador. As células solares foram então caracterizadas por curvas I-V utilizando um potenciostato Autolab PGSTAT $10 \mathrm{com}$ velocidade de varredura de $10 \mathrm{mV} . \mathrm{s}^{-1}$. As 
caracterizações foram feitas com irradiação de luz policromática com intensidades de $10 \mathrm{~mW} . \mathrm{cm}^{-2}$ e $100 \mathrm{~mW} . \mathrm{cm}^{-2}$. O banco ótico foi constituído de uma lâmpada de XenônioMercúrio, lentes de colimação de feixe e filtro AM 1.5. A intensidade de luz foi calibrada utilizando um radiômetro Newport Optical Power Meter 1830-C. Todas as medidas foram efetuadas após um tempo de estabilização de 15 minutos.

Com todas as informações citadas, pôde-se realizar todos os objetivos do trabalho. Tanto as técnicas de caracterização (espectroscópicas, térmicas e eletrônicas) como a técnica que determina a condutividade dos ESPs são importantes no sentido de fornecer dados que demonstram os acontecimentos envolvidos nos objetivos que serão apresentados na página seguinte. 


\section{RESULTADOS E DISCUSSÃO}

\subsection{Determinação da quantidade de Glicerol}

No sentido de estabelecer a formulação para a obtenção de eletrólitos à base de gelatina, as amostras foram preparadas com diferentes quantidades de plastificante, i.e., glicerol e subseqüentemente foram realizadas as medidas de condutividade. A Tabela 3 revela os resultados dessas análises onde se observa que o aumento de quantidade de glicerol promove o aumento de condutividade iônica como já foi observado nos estudos similares com eletrólitos à base de gelatina, contendo ácido acético ou outros sais para a promoção da condutividade ${ }^{12}$. Contudo nos presentes ensaios foi observado que apesar da quantidade de $3 \mathrm{~g}$ de glicerol, na formulação das membranas, levar à obtenção de condutividades iônicas mais elevadas, as mesmas apresentaram os processos de excudação e/ou sinérese, i.e. expulsão de líquido do gel e fraca aderência ao vidro e metal. Portanto, para os estudos foi considerada a amostra com $2,5 \mathrm{~g}$ de glicerol por apresentar boa homogeneidade visual, boa transparência, flexibilidade e boa aderência ao vidro e metal.

Tabela 3 - Valores de condutividades iônicas das amostras com diferentes quantidades de glicerol

\begin{tabular}{cccc}
\hline Amostra & LI// $\mathbf{2}(\mathbf{g})$ & Glicerol $\mathbf{( g )}$ & Condutividade $\left(\mathbf{S} . \mathbf{c m}^{-1}\right)$ \\
\hline G4 & 0,9 & 2 & $4,39 \times 10^{-5}$ \\
G4 & 0,9 & 2,5 & $4,12 \times 10^{-5}$ \\
G4 & 0,9 & 3 & $6 \times 10^{-5}$
\end{tabular}

Obs: Todos os valores foram obtidos em $25^{\circ} \mathrm{C}$.

Por outro lado é importante ressaltar que uma quantidade em massa de plastificante elevada melhora a condutividade no sentido de facilitar a mobilidade dos íons devido à diminuição da cristalinidade das amostras e aumento do volume livre $12,13,14$ 
Analisou-se por espectroscopia no infravermelho a amostra G4 para identificar os principais grupos orgânicos presentes. A Figura 24 mostra o resultado desta análise onde na região de $3440 \mathrm{~cm}^{-1}$ se observa uma banda muito intensa e larga devida as hidroxilas provenientes do glicerol. Na região de $2900 \mathrm{~cm}^{-1}$ há duas bandas menores relativas às vibrações de grupos $\mathrm{CH}$ e na região de $1730 \mathrm{~cm}^{-1}$ a banda relativa às carbonilas presentes nas macromoléculas de gelatina. E na região de $1450 \mathrm{~cm}^{-1}$, observa-se bandas relativas às ligações $\pi$.

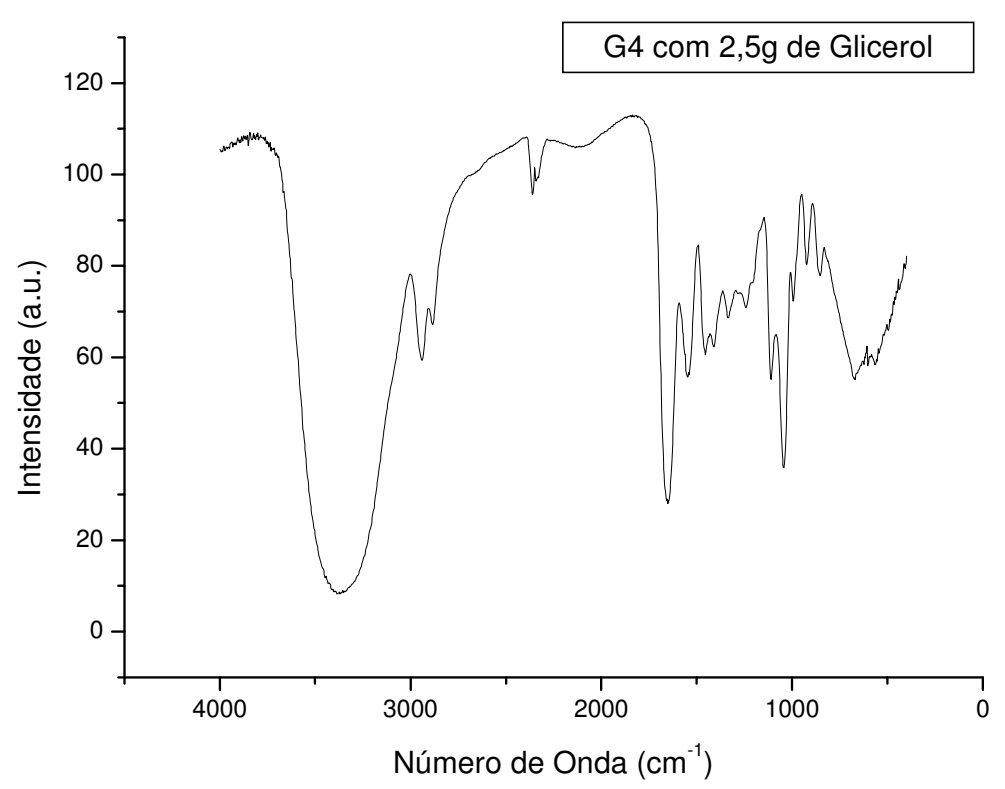

Figura 24 - Espectro no infravermelho da amostra de G4. 


\subsection{Condutividade dos EPSs}

\subsubsection{Teste da Condutividade}

Antes de realizar as determinações das condutividades, foi necessário saber a partir de qual tempo, e durante qual período, as mesmas são mantidas constantes. Após a conclusão de uma medida da amostra de ESP, monitorou-se as variações dos valores de condutividade realizando análises de impedância todos os dias. O resultado destes ensaios está mostrado na Figura 25. Observa-se no gráfico uma queda considerável no valor da condutividade até o quarto dia de medida de $6,29 \times 10^{-5} \mathrm{~S} / \mathrm{cm}$ até $1,14 \times 10^{-5} \mathrm{~S} / \mathrm{cm}$, tempo em que a amostra foi mantida em ambiente aberto, e uma pequena variação na condutividade após 4 dias, que foi o tempo em que a amostra foi mantida para secagem em dessecador. E concomitantemente a essa variação de condutividade foram feitas análises de difração de Raios $X$ para observar eventuais mudanças estruturais das amostras.

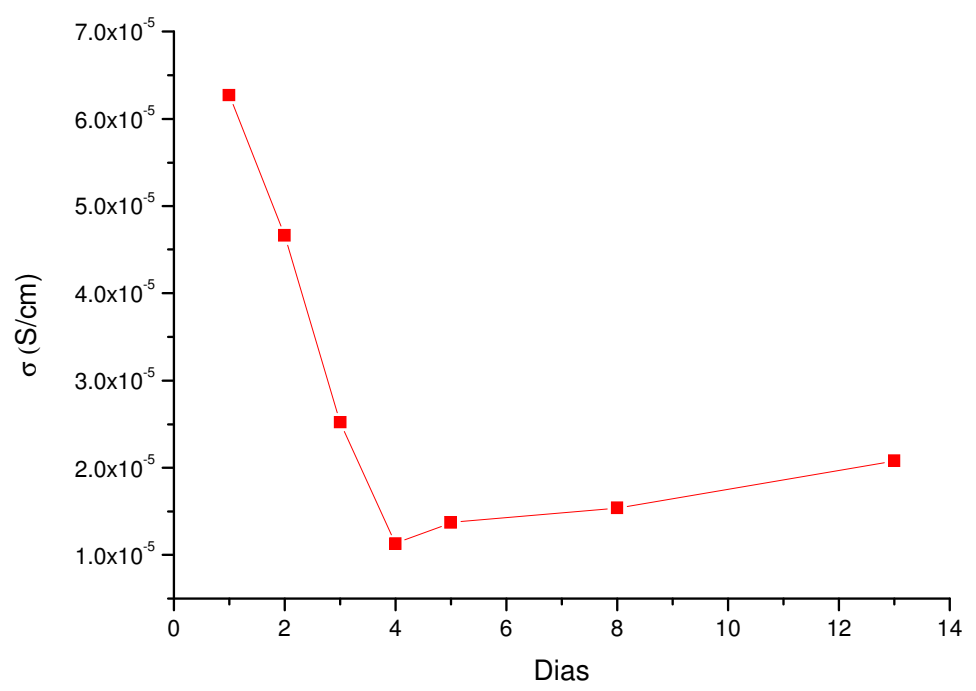

Figura 25 - Variação da condutividade em função do tempo de exposição da amostra G4 ao ambiente do laboratório. 
Observa-se que a partir do quarto dia, a condutividade de G4, uma vez que a quantidade ideal de glicerol foi definida, não apresenta um aumento abrupto, principalmente entre o $5^{\circ}$ e $\circ 8^{\circ}$ dias. Sendo assim, todas as medidas, foram realizadas no intervalo determinado pelo teste da condutividade. Convencionou-se que todas as análises, mesmo em triplicata, foram realizadas no período determinado. $O$ comportamento observado no gráfico pode ser explicado devido à perda de água até o 4ํ dia, após o tempo de estabilidade, que resultou numa oscilação nos valores da condutividade, fato que pode ser explicado devido à presença do sal, que é altamente higroscópico aumentando levemente a condutividade.

A Figura 26 mostra os cinco difratogramas obtidos de G4 em dias consecutivos, nos quais, observa-se que o fato da exposição das amostras no ambiente do laboratório e o tempo da análise não influíram significativamente nos difratogramas da amostra evidenciando o caráter predominantemente amorfo das mesmas.

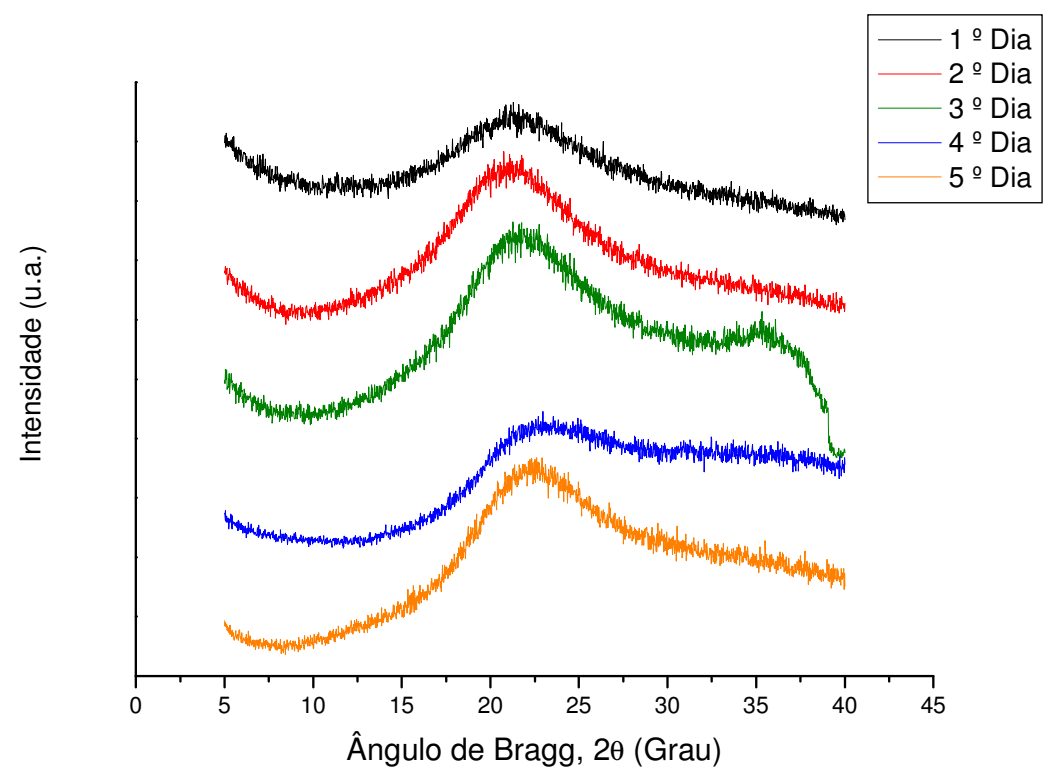

Figura 26 - Difratogramas de G4 realizados durante 5 dias consecutivos. 


\subsubsection{Valores de Condutividade dos ESPs}

Uma vez que a quantidade ideal de glicerol foi determinada e que o tempo para a análise das condutividades foi definido, pôde-se analisar a quantidade de $\mathrm{Lil} .2 \mathrm{H}_{2} \mathrm{O} / \mathrm{I}_{2}$ que resultou na obtenção das amostras com maiores condutividades iônicas. Para isso, preparou-se cinco amostras com diferentes quantidades em porcentagem desse par redox. Todas as análises foram feitas em triplicata, sendo assim, pôde-se determinar as condutividades médias em temperatura ambiente de todas as amostras. A Tabela 4 mostra os valores de cada medida. A partir destes dados foram calculadas as condutividades médias dos ESPs, apresentados na Tabela 5.

Como não foi possível obter os valores de condutividade em $25 \stackrel{\circ}{\circ}$ para todas as amostras, os mesmos foram recalculados dos ajustes dos dados colhidos. Assim no eixo $X$ do gráfico de $\log \sigma(\mathrm{S} / \mathrm{cm}) \times 1000 \mathrm{~T}^{-1}(\mathrm{~K})$, logo, dividiu-se 1000 por $298,15 \mathrm{~K} \mathrm{e}$ obteve-se o valor de 3,356. Com o auxilio do Microcal Origin 7.5, pôde-se determinar o valor de $Y$ correspondente a 3,356 do eixo $X$ para cada medida de cada amostra, sendo assim o antiLog do valor de $\mathrm{Y}$ correspondente a $25^{\circ} \mathrm{C}$ resultou no valor de $\sigma$ para cada amostra.

Tabela 4 - Valores de condutividade iônica para cada medida para diferentes quantidades de sal de lítio

\begin{tabular}{|c|c|c|c|}
\hline Amostra & $1^{\circ}$ Medida $\left(\mathrm{S} . \mathrm{cm}^{-1}\right)$ & $2^{0}$ Medida $\left(\mathrm{S} \mathrm{cm}^{-1}\right)$ & $3^{\circ}$ Medida $\left({\left.\mathrm{S} . \mathrm{cm}^{-1}\right)}\right.$ \\
\hline Gelatina 1 (G1) & $4,59 \times 10^{-5}$ & $6,85 \times 10^{-5}$ & $1,16 \times 10^{-4}$ \\
\hline Gelatina 2 (G2) & $5,8 \times 10^{-5}$ & $9,56 \times 10^{-5}$ & $3,79 \times 10^{-5}$ \\
\hline Gelatina 3 (G3) & $1,15 \times 10^{-4}$ & $7,06 \times 10^{-5}$ & $7,90 \times 10^{-5}$ \\
\hline Gelatina 4 (G4) & $1,05 \times 10^{-4}$ & $1,09 \times 10^{-4}$ & $7,95 \times 10^{-5}$ \\
\hline Gelatina 5 (G5) & $6,88 \times 10^{-5}$ & $8,92 \times 10^{-5}$ & $7,81 \times 10^{-5}$ \\
\hline
\end{tabular}

A Tabela 5 mostra que a amostra G4 apresentou os valores de condutividade mais elevados quando comparados as outras amostras. 
Tabela 5 - Valores médios de condutividade para diferentes quantidades do par redox

\begin{tabular}{ccc}
\hline Amostra & Lil.2 $\mathrm{H}_{2} \mathbf{O} / \mathrm{I}_{2}(\%)$ & Condutividade (S.cm) \\
\hline G1 & 30 & $7,68 \times 10^{-5}$ \\
G2 & 35 & $6,38 \times 10^{-5}$ \\
G3 & 40 & $8,81 \times 10^{-5}$ \\
G4 & 45 & $9,97 \times 10^{-5}$ \\
G5 & 50 & $7,87 \times 10^{-5}$
\end{tabular}

Obs: Todos os valores foram obtidos em $25^{\circ} \mathrm{C}$.

Observa-se também na Figura 27, que a partir de uma quantidade maior que $45 \%$ de Lil// $I_{2}$ com relação à massa da matriz (gelatina), ocorre uma diminuição no valor da condutividade média, fato que pode ser explicado devido à saturação da amostra. A mesma tem a condutividade prejudicada com excesso de sal, e, portanto isso faz com que a mobilidade iônica diminua por causa da formação de cristais do sal ${ }^{18}$.

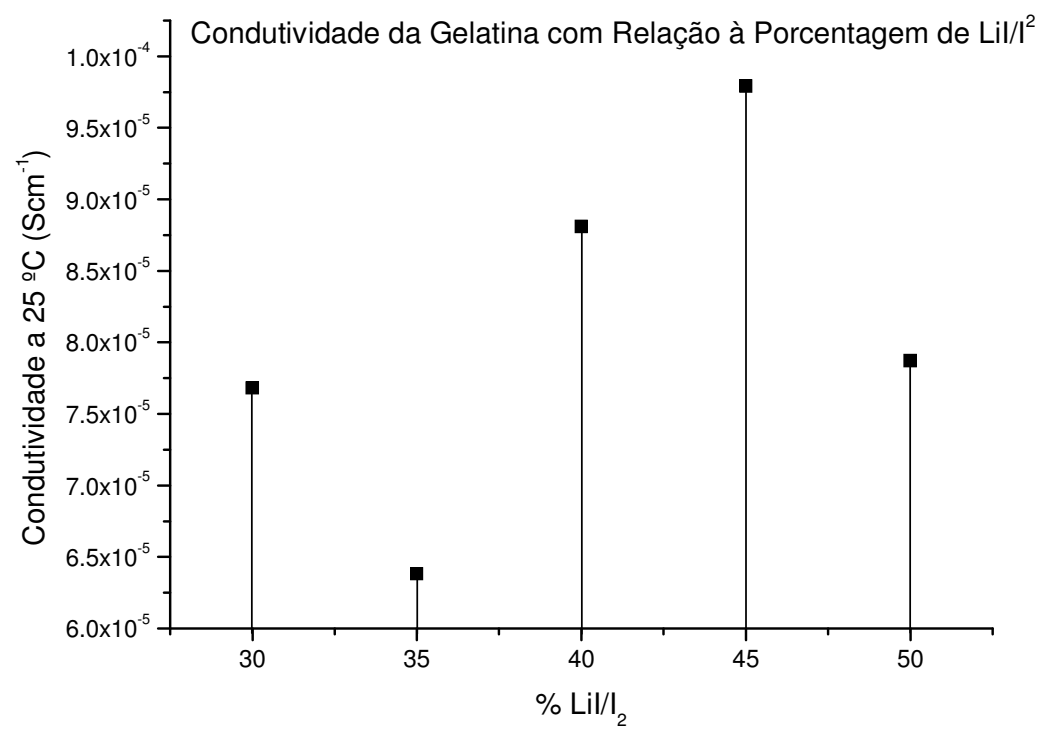

Figura 27 - Valores de condutividade para diferentes porcentagens de $\mathrm{Lil} / \mathrm{I}_{2}$.

Observa-se que todos os eletrólitos analisados apresentaram comportamento VTF. Logo, para a determinação da energia de ativação (Ea) dos ESPs, foi necessária a análise térmica por DSC dos mesmos. Os resultados das condutividades em função da temperatura das amostras de G1-G5 estão mostrados nas Figuras 28-32. 


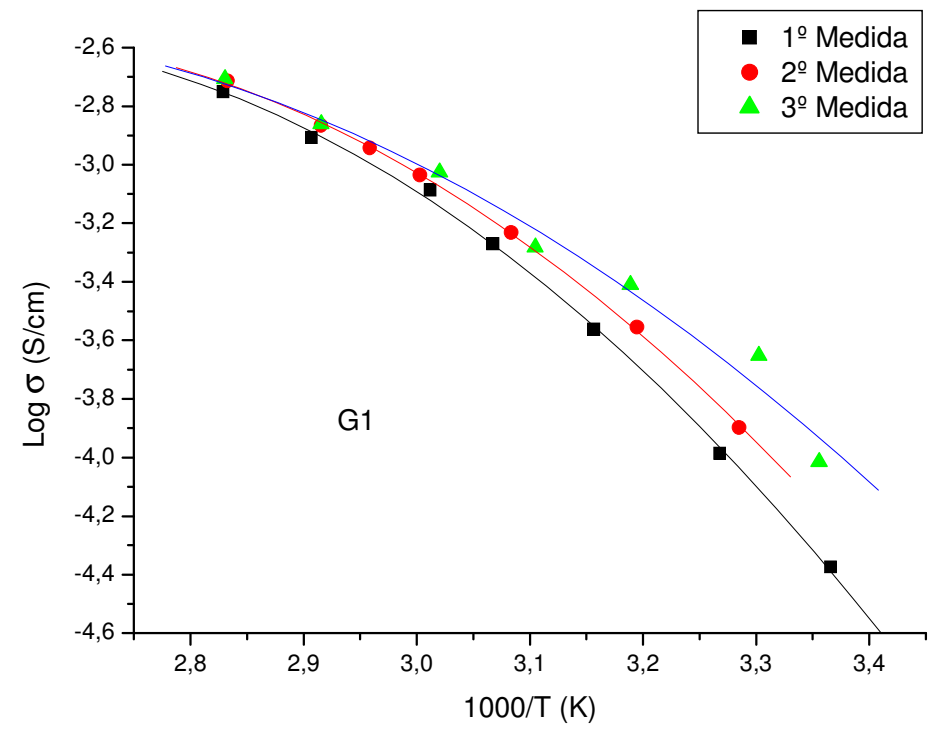

Figura 28 - Valores das condutividades iônicas em função do inverso da temperatura, em triplicata da amostra G1.

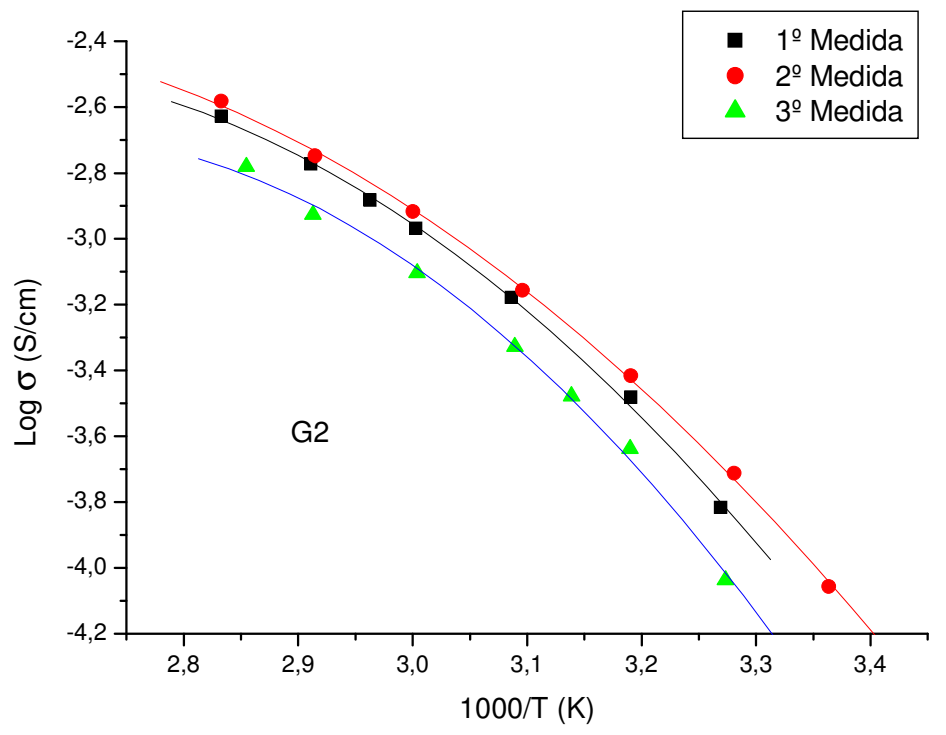

Figura 29 - Valores das condutividades iônicas em função do inverso da temperatura, em triplicata da amostra G2. 


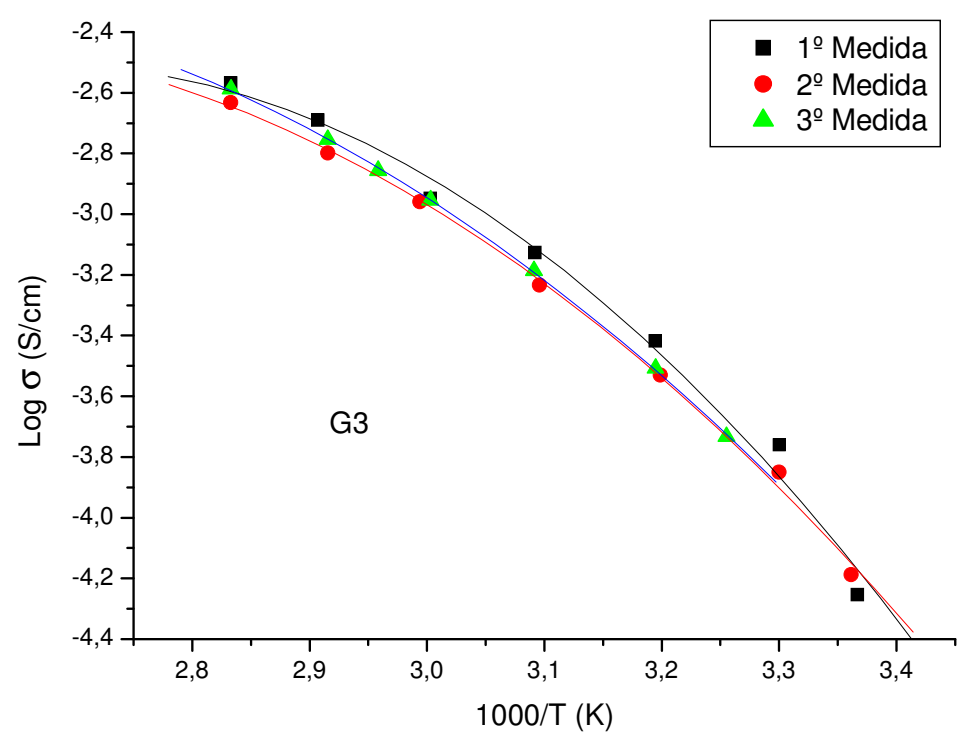

Figura 30 - Valores das condutividades iônicas em função do inverso da temperatura, em triplicata da amostra G3.

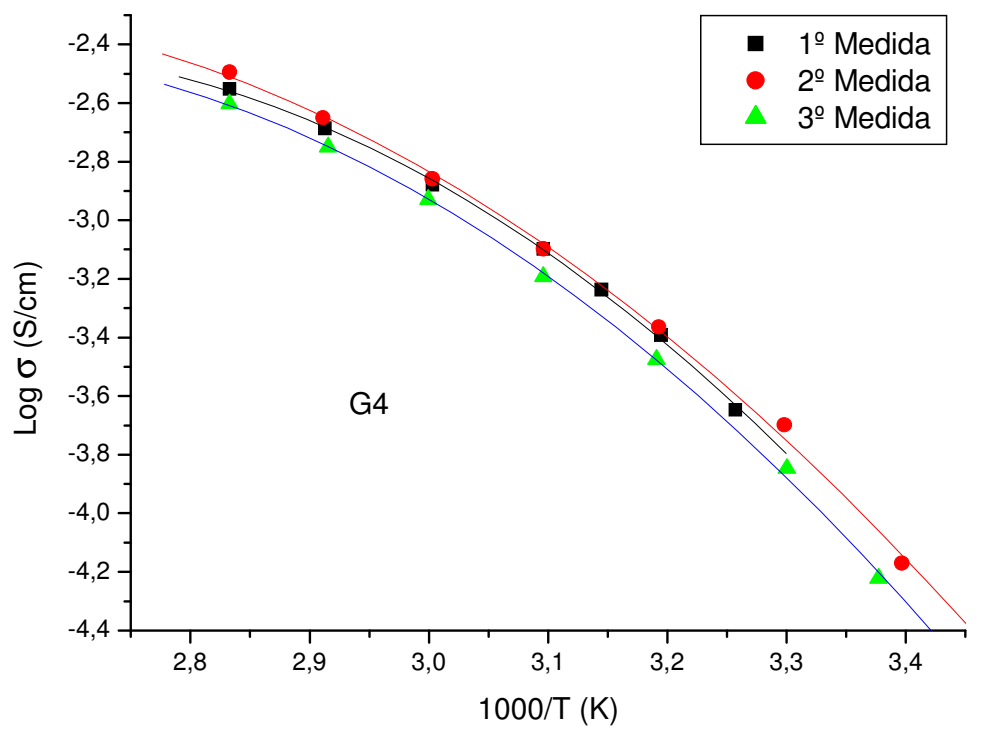

Figura 31 - Valores das condutividades iônicas em função do inverso da temperatura, em triplicata da amostra G4. 


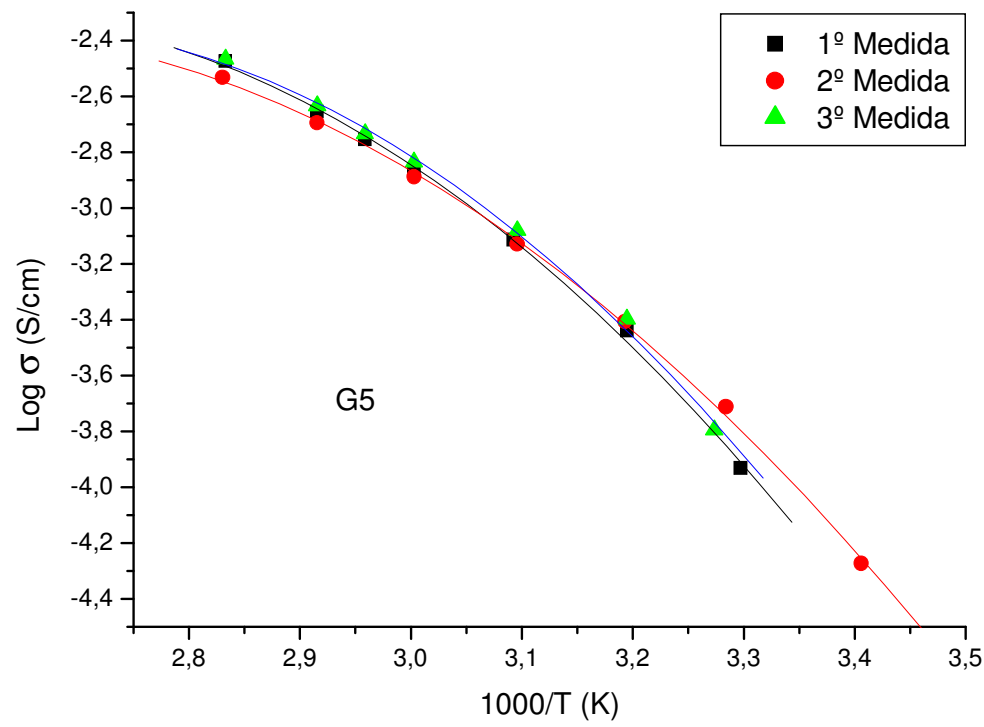

Figura 32 - Valores das condutividades iônicas em função do inverso da temperatura, em triplicata da amostra G5.

Um comparativo com todos os resultados dos valores de condutividade iônica em função ao inverso da temperatura médios dos EPS foi realizado, para enfatizar que a Gelatina 4 (G4) apresentou ligeiramente melhor condutividade. A Figura 33 mostra o gráfico, no qual se pôde chegar a tal conclusão, embora a diferença no valores esteja dentro do erro de medida. 


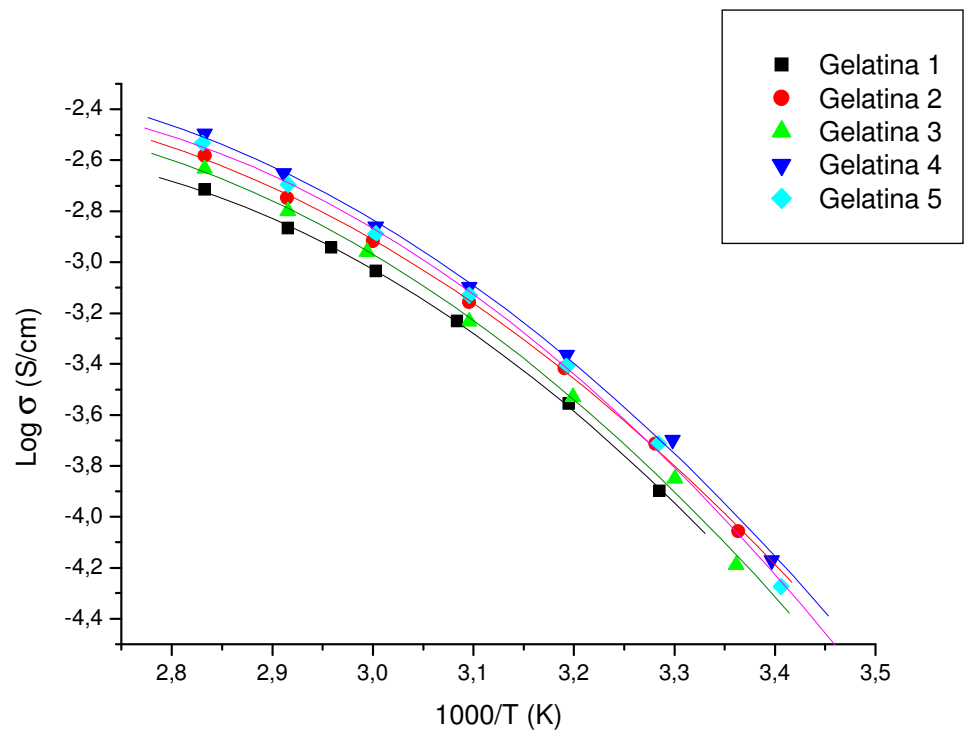

Figura 33 - Valores das condutividades iônicas em função do inverso da temperatura, em triplicata da amostra ESP.

As condutividades das amostras foram analisadas através das medidas de condutividade iônica em função da temperatura ${ }^{18}$. Os fatos que justificam as boas condutividades dos ESPs à base de gelatina comercial com Lil e $\mathrm{I}_{2}$, na ordem de $10^{-5}$, foram os comportamentos dos gráficos de condutividade se apresentaram de acordo com o modelo VTF, ou seja, não só o teor de sal determinou estes bons valores de condutividade, mas também a mobilidade iônica que a matriz do eletrólito proporcionou $^{20}$. 


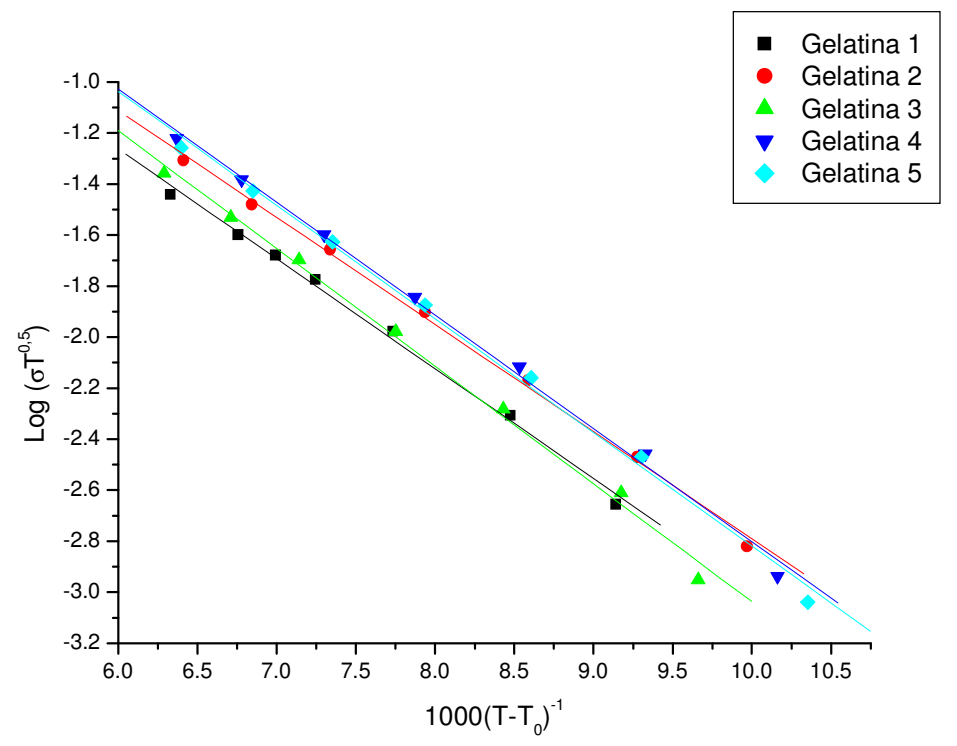

Figura 34 - Ajuste dos valores de condutividade iônica de acordo com o modelo VTF, onde To=Tg-50K.

A Figura 34 mostra os ajustes dos valores de condutividades iônicas de acordo com o modelo VTF. Como pode ser observado nesta figura todos os resultados foram ajustados com linhas retas comprovando o modelo de condutividade sendo VTF. Sendo assim, pôde-se calcular a energia de ativação (Ea) dos ESPs, cujos resultados estão mostrados na Tabela 6 . Os valores obtidos foram calculados através da identificação das Tgs das 5 amostras nos gráficos de DSC, esses que serão apresentados a seguir.

Tabela 6 - Valores de Energia de Ativação dos ESPs

\begin{tabular}{cc}
\hline Eletrólito & Ea (kJ. $\mathbf{m o l}^{-1}$ ) \\
\hline G1 & 8,24 \\
G2 & 8,04 \\
G3 & 8,83 \\
G4 & 8,49 \\
G5 & 8,53 \\
\hline
\end{tabular}

Observa-se que os valores de Ea não correspondem com as curvas de condutividade, i.e. quanto maior valor de condutividade deveria se obter menor valor de energia livre, e onde a Gelatina 4 foi apontada como o melhor condutor. Isso pode ser 
devido ao fato de que a linearização das curvas gera erros, pois a reta traçada não passa por todos os pontos em nenhum eletrólito. Por outro lado, tanto os valores de $\mathrm{Ea}$ como os valores de condutividades iônicas são bastante próximos, estando dentro dos erros das medidas e dos ajustes. A energia de ativação é um grande indicativo para a condutividade, pois quanto menor o valor maior será a cinética do processo de condução, mas a Ea é somente um indicativo cinético e as curvas de condutividade mostram com mais clareza os melhores ESPs.

\subsubsection{Janela Eletroquímica}

Na Figura 35 apresenta-se um gráfico do Log da condutividade em função do potencial aplicado ao eletrólito em $25^{\circ} \mathrm{C}$. Nota-se que para uma faixa de potencial que varia de $-4,5 \vee \mathrm{a}+4,5 \mathrm{~V}$, o valor da condutividade permanece quase constante, indicando que não há nenhuma reação eletrolítica. Entretanto, ao passar para $-5 \mathrm{~V}$ ou +5V ocorreu uma destruição do ESP, que pôde ser notada visualmente. Desta forma, constatou-se que não foi possível determinar no qual exatamente valor de potencial o ESP começa a sofrer alguma mudança estrutural, embora aparentemente abaixo de 4,5V e acima de 4,5V. 


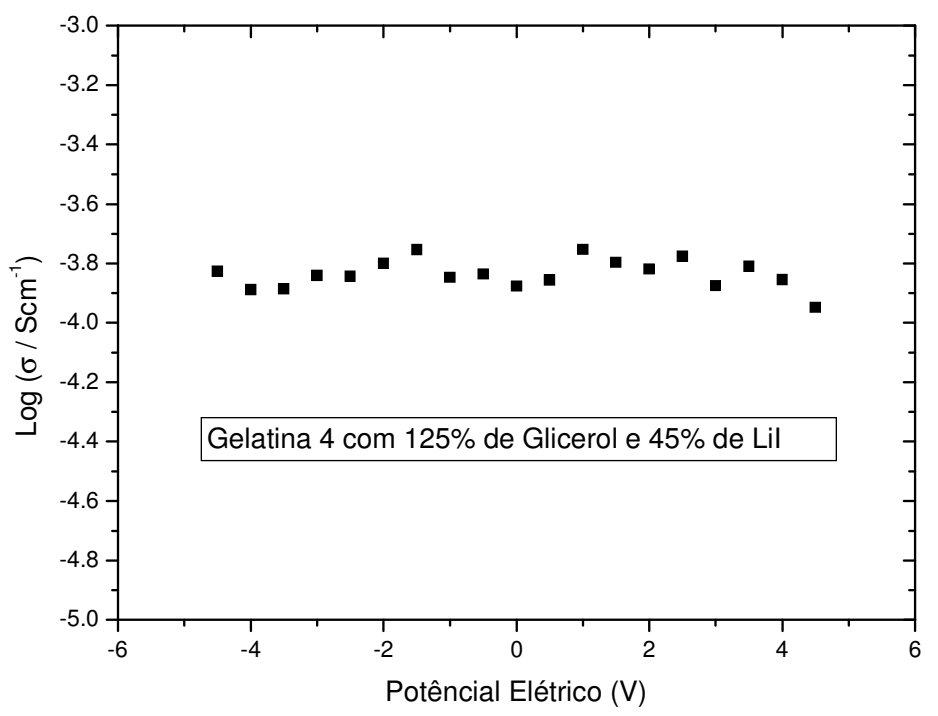

Figura 35 - Janela de Potencial apresentada pela amostra G4.

\subsubsection{Teste do Resfriamento}

Após todos os testes de condutividades realizados, outro teste importante realizado foi a reprodutibilidade dos valores das amostras de ESPs após a primeira vez em que foram submetidos ao aquecimento. A importância desse teste é saber o comportamento do eletrólito ao ser submetido a aquecimento pela segunda vez. A Figura 36 mostra uma EIE da amostra G4 do primeiro e segundo ciclos de aquecimento. 


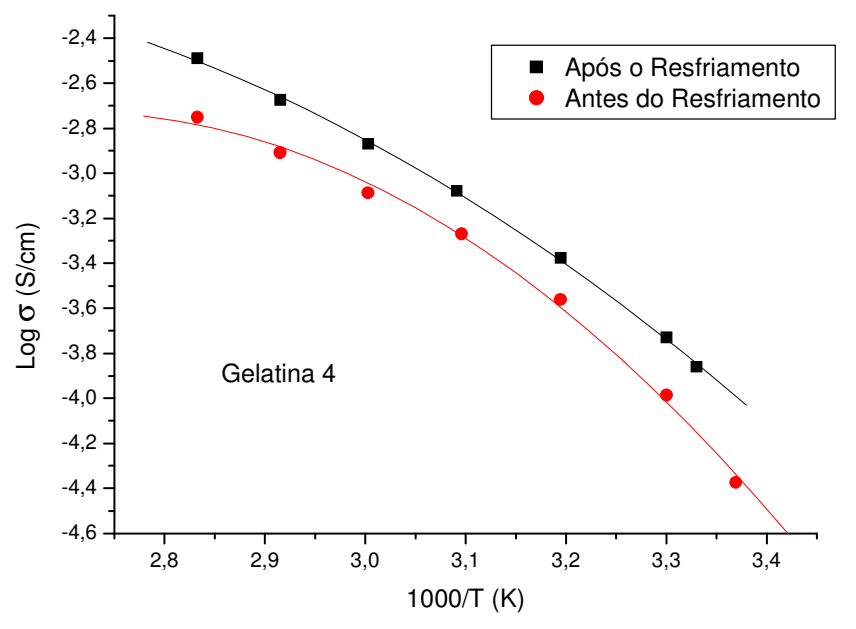

Figura 36 - Valores de condutividades iônica em função do inverso da temperatura do primeiro e segundo ciclo de aquecimento da amostra G4.

Pôde-se observar que ocorre um pequeno aumento nos valores de condutividade no intervalo inteiro de temperatura do ensaio. Contudo pode ser observado que este aumento é realmente pequeno, ficando dentro do erro da medida. Também este aumento da condutividade pode ser o resultado das possíveis mudanças irreversíveis quando o eletrólito é submetido a uma alta temperatura ${ }^{27}$.

\subsection{Análise no Ultravioleta e Visível}

Para que os ESPs sejam aplicados em células solares, os mesmos requerem uma boa transparência na região do visível do espectro eletromagnético, devido à presença de um par redox nas camadas de armazenamento dos ESPs, ao invés de simples íons ${ }^{23}$. Como se pode observar na Figura 37, as amostras G1, G2 e G5 apresentaram uma transparência em torno de $89 \%$ e as amostras G3 e G4 apresentaram $80 \%$ de transparência. Como a transparências das amostras depende também das espessura das mesmas a Tabela 7 mostra que os eletrólitos na forma de membranas tiveram as espessuras bastante parecidas, em torno de $0,04 \mathrm{~cm}$. 
Tabela 7 - Valores de espessura das amostras dos ESPs

\begin{tabular}{cc}
\hline Amostra & Espessura (cm) \\
\hline G1 & 0,0384 \\
G2 & 0,0475 \\
G3 & 0,0440 \\
G4 & 0,0437 \\
G5 & 0,0412
\end{tabular}

Embora as amostras apresentem valores de transmitância muito próximos, as transparências das mesmas variam entre $89 \%$ e $80 \%$ no intervalo entre 550 e 800 nm. Vale ressaltar que, segundo Vieria e col. ${ }^{12}$, as transmitâncias diminuem com uma maior quantidade de sal o que também foi verificado neste ensaio. Contudo a amostra G4, embora possua uma quantidade elevada de sal, mesmo assim apresentou um bom valor de transmitância.

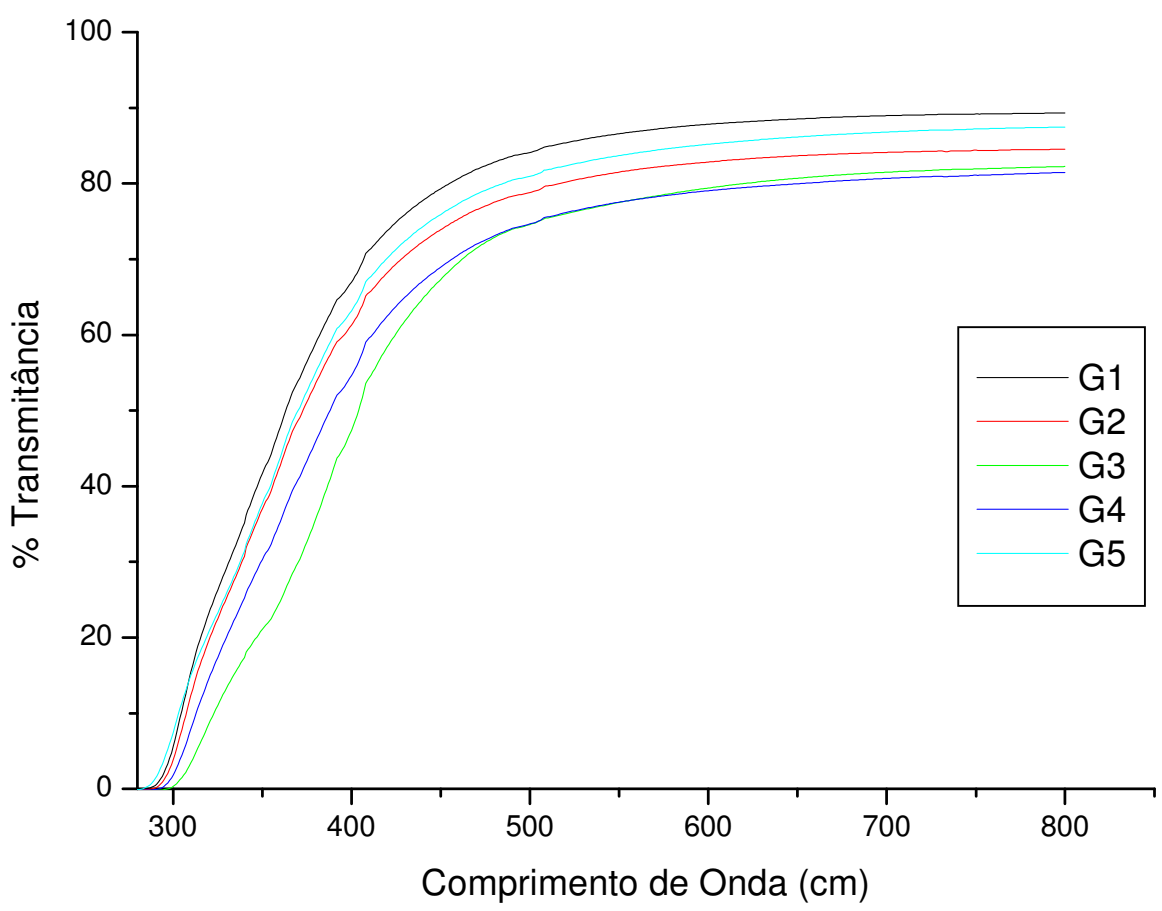

Figura 37 - Espectros de ultravioleta e visível dos ESPs de G1-G5. 
Os resultados obtidos para as amostras de ESPs contendo Lil// 2 são bastante parecidos com as amostras contendo sais de lítio ou ácido acético, onde transmitâncias em torno de $80 \%$ foram registradas ${ }^{18}$. Também no caso das amostras com par redox iodeto de lítio/iodo observa-se um aumento na transmitância de quase $0 \%$ na região do Ultravioleta a partir de $300 \mathrm{~nm}$, chagando a $80 \%$ em $450 \mathrm{~nm}$ e $90 \%$ em $600 \mathrm{~nm}$.

\section{5 - Difração de Raios X}

Com o objetivo de analisar a estrutura das amostras foram realizadas análises por difração de Raios X. A Figura 38 mostra os difratogramas de todos os ESPs estudados.

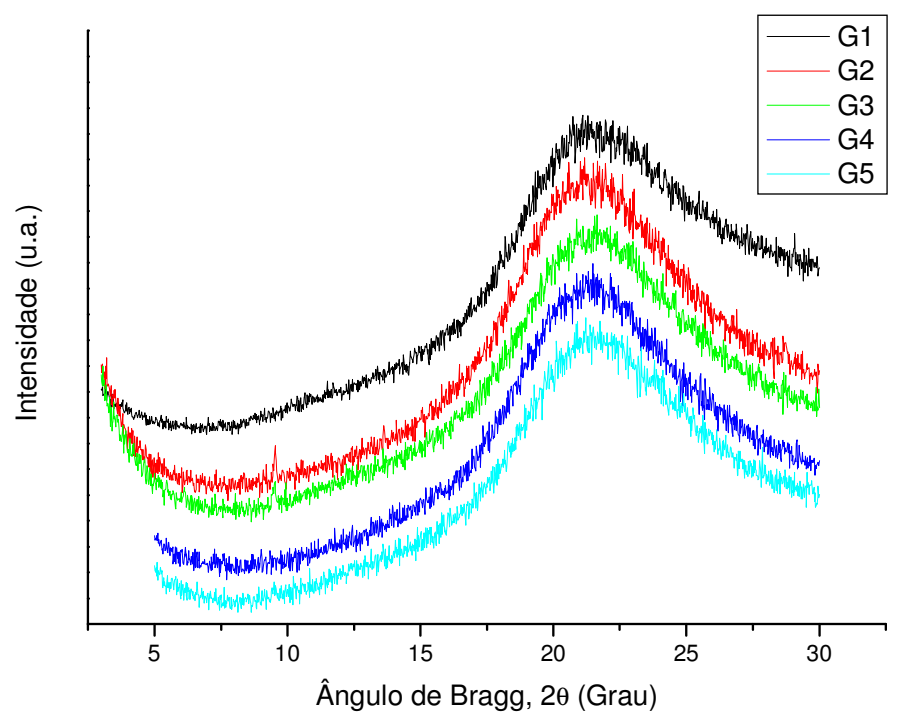

Figura 38 - Difratograma das amostras G1-G5.

Os resultados colhidos durante estas análises revelaram picos cristalográficos centrados em $2 \theta=22^{\circ}$ para todas as amostras indicando o caráter predominantemente amorfo das membranas condutoras iônicas de modo similar às amostras de outros ESPs à base de gelatina ${ }^{12}$. 


\subsection{Calorimetria Exploratória Diferencial}

As medidas de calorimetria diferencial exploratória (DSC) foram efetuadas no intuito de analisar o comportamento térmico das amostras e principalmente observar a possível existência da temperatura de transição vítrea, cujo valor é importante para o desenvolvimento de eletrólitos poliméricos. Efetivamente como pôde ser observado nos gráficos das Figuras 39, 40, 41, 42 e 43, as amostras apresentaram as Tgs bastantes significativas em temperatura baixas em torno de $-78^{\circ} \mathrm{C}$, como mostrado na Tabela 7. Os valores de $\mathrm{Tg}$ equivalem a uma média dos valores de $\Delta \mathrm{C}_{\mathrm{p}}$ obtidos nos pontos marcados dos gráficos abaixo ${ }^{27}$.

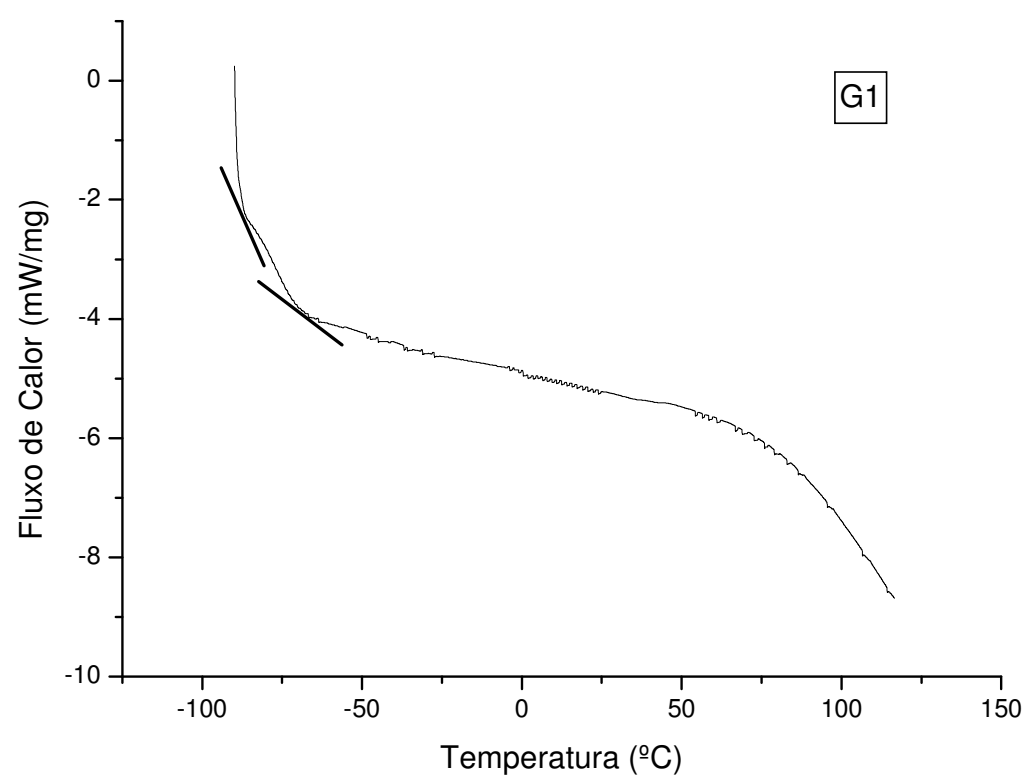

Figura 39 - Curva de DSC da amostra de G1. 


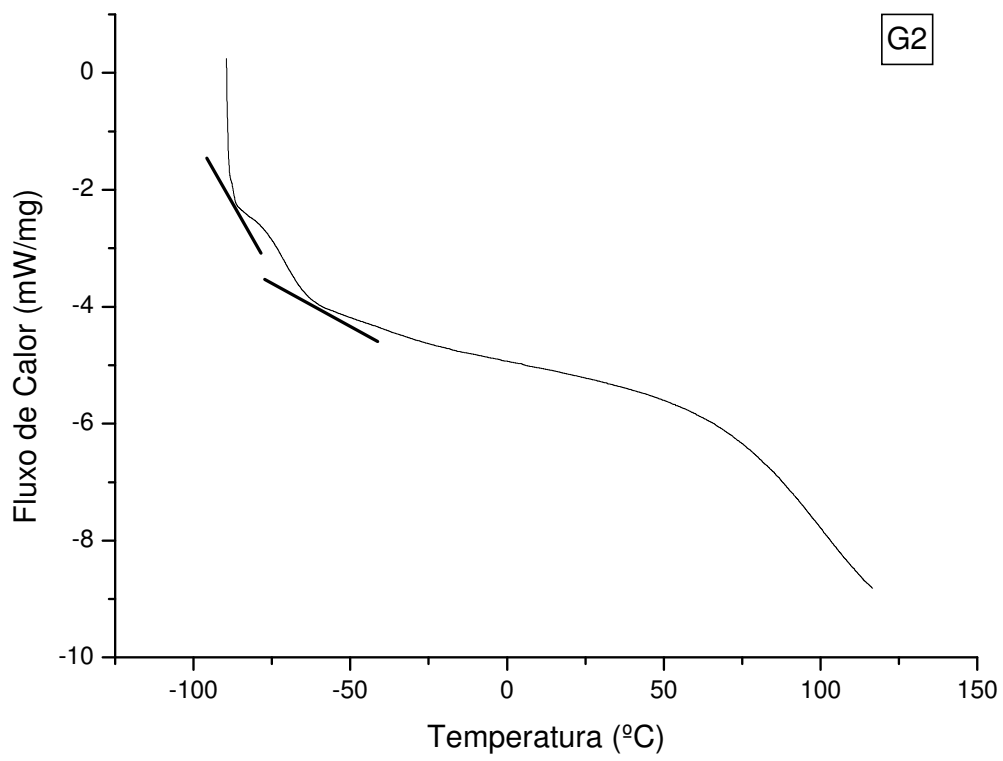

Figura 40 - Curva de DSC da amostra de G2.

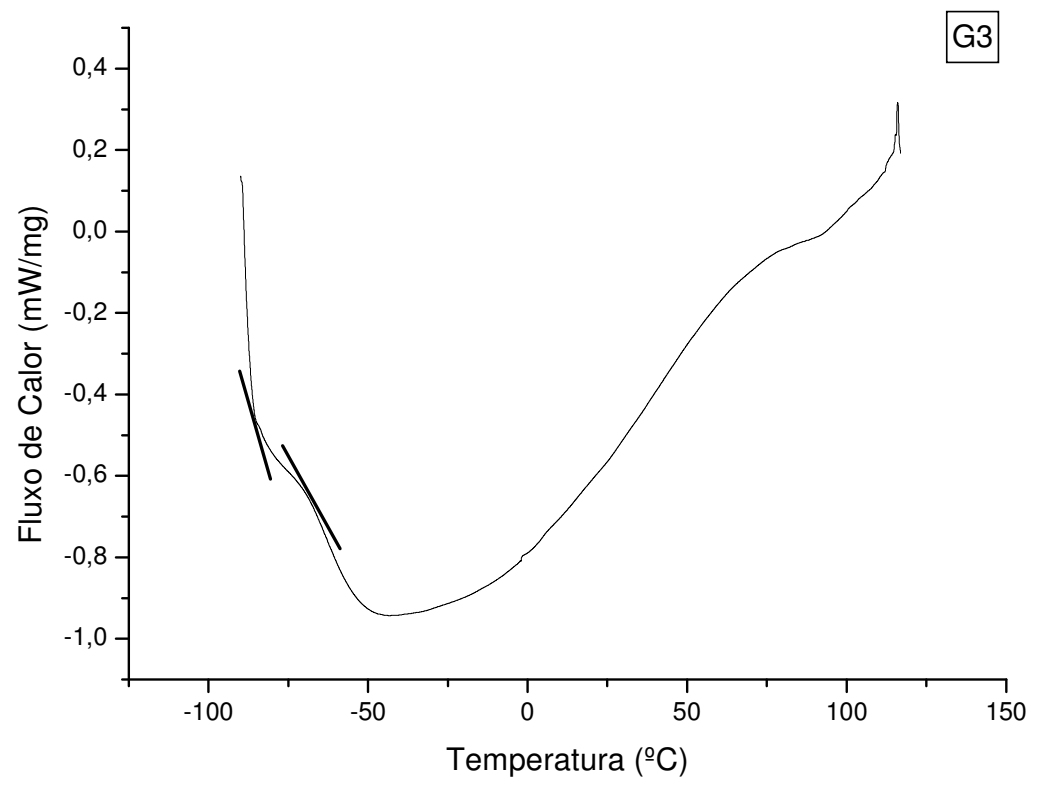

Figura 41 - Curva de DSC da amostra de G3. 


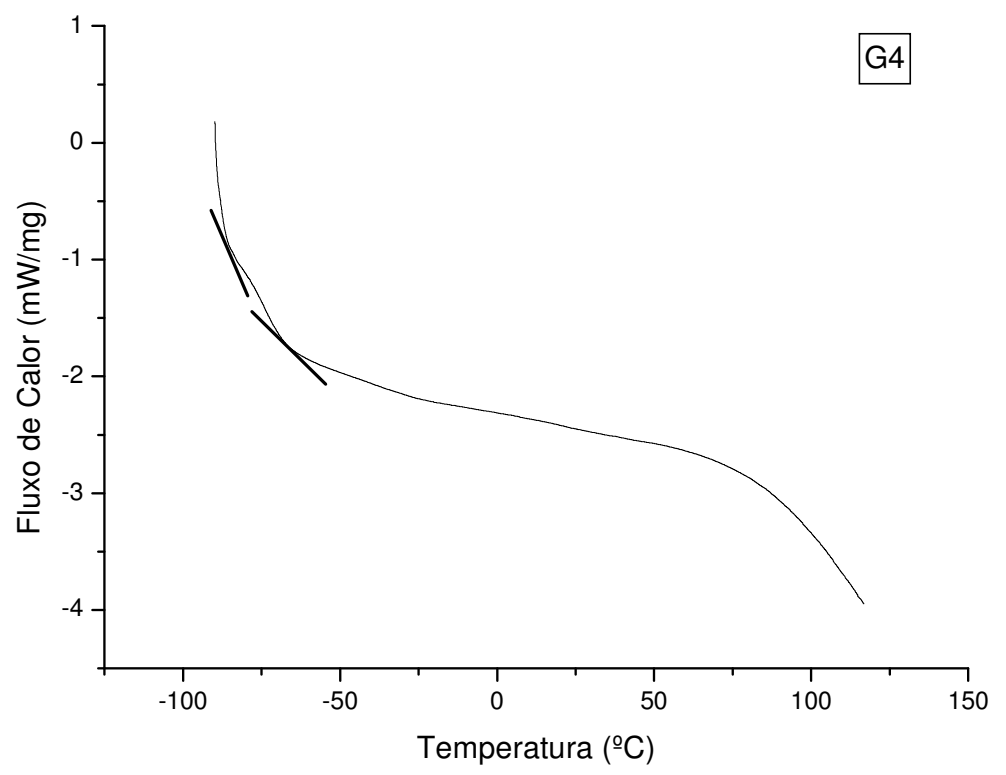

Figura 42 - Curva de DSC da amostra de G4.

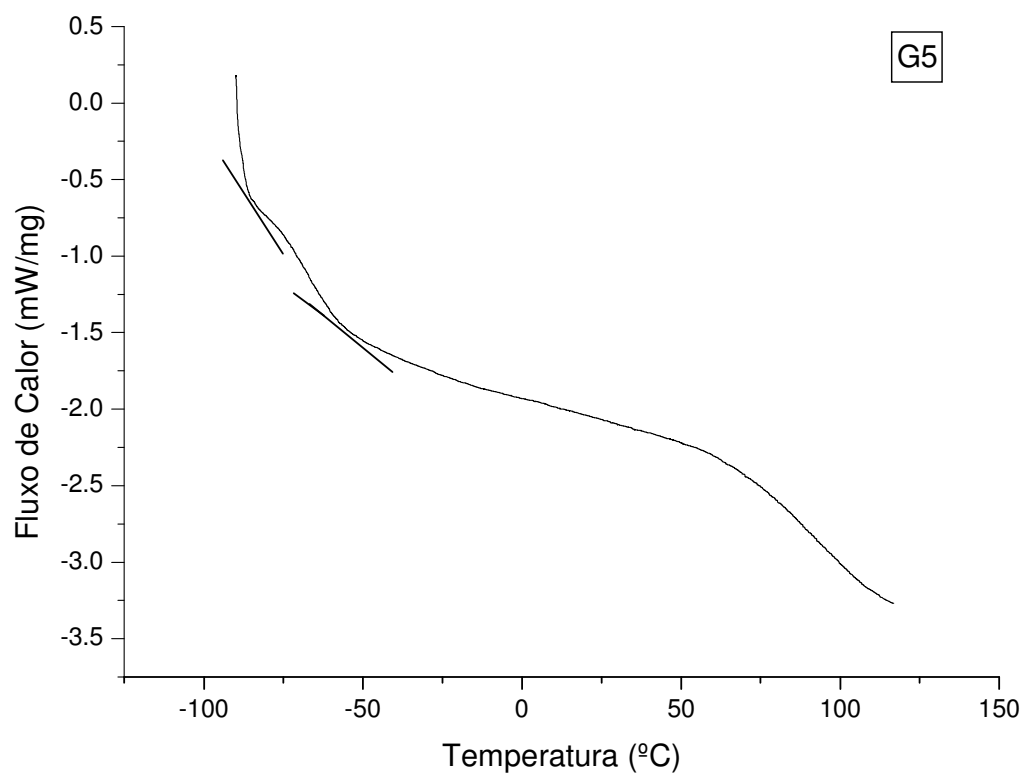

Figura 43 - Curva de DSC da amostra de G5. 
A Tabela 8 apresenta os valores de Tg referentes a cada \% de Lil utilizado na produção dos eletrólitos.

\begin{tabular}{ccc}
\multicolumn{3}{c}{ Tabela 8 - Temperatura de transição vítrea em das amostras } \\
\hline Amostras & Lil (\%) & Tg (-C) \\
\hline G1 & 30 & -78 \\
G2 & 35 & -76 \\
G3 & 40 & -79 \\
G4 & 45 & -77 \\
G5 & 50 & -76 \\
\hline
\end{tabular}

\subsection{Microscopia Eletrônica de Varredura}

As superfícies dos ESPs à base de gelatina comercial com Lil e $\mathrm{I}_{2}$, com o auxílio de um microscópio eletrônico de varredura, estão representadas nas Figuras 44, 45, 46, 47 e 48. Todas as micrografias foram realizadas com uma ampliação de 5000x. Um aumento maior não foi possível, pois o aumento na intensidade no feixe de elétrons danificou as amostras, não permitindo uma boa visualização das mesmas.

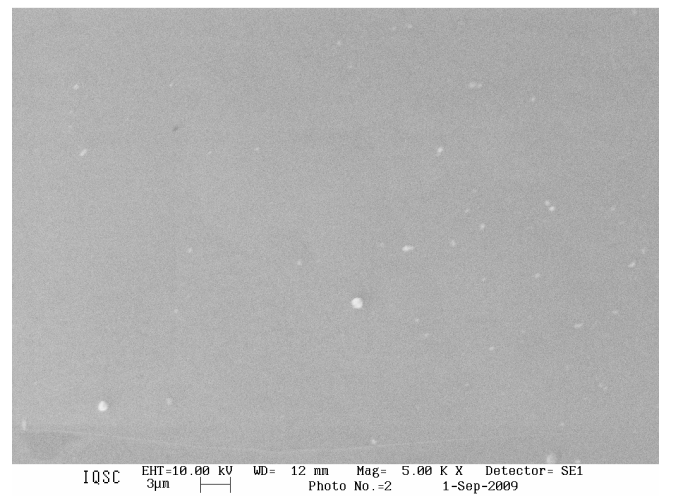

Figura 44 - Micrografia da amostra G1

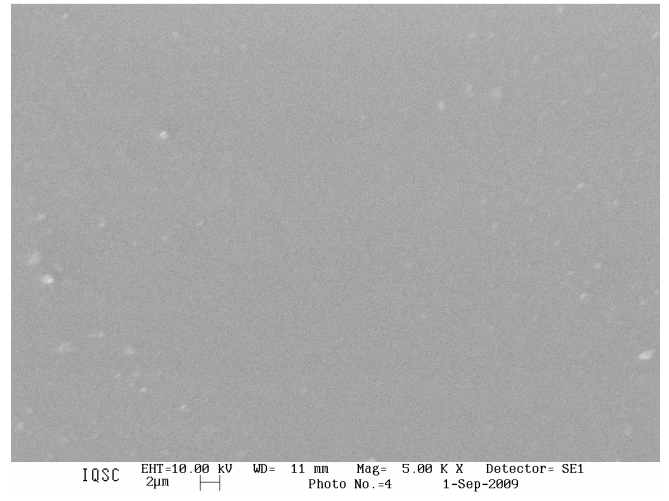

Figura 45 - Micrografia da amostra G2 


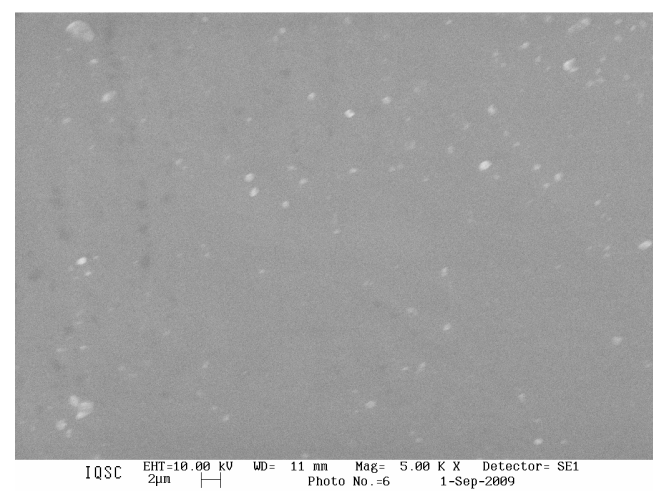

Figura 46 - Micrografia da amostra G3

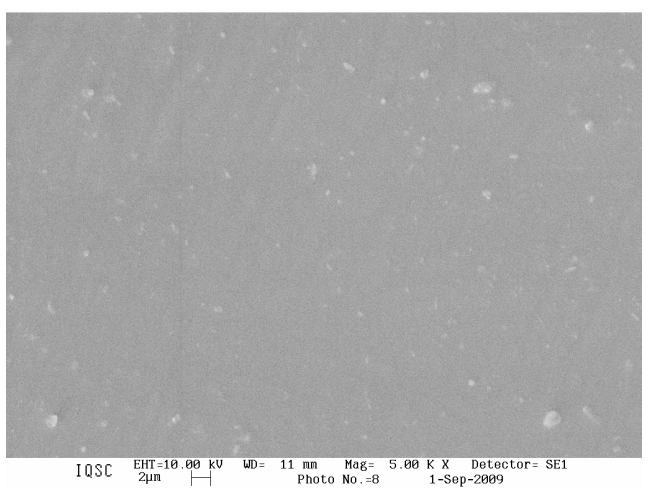

Figura 47 - Micrografia da amostra G4

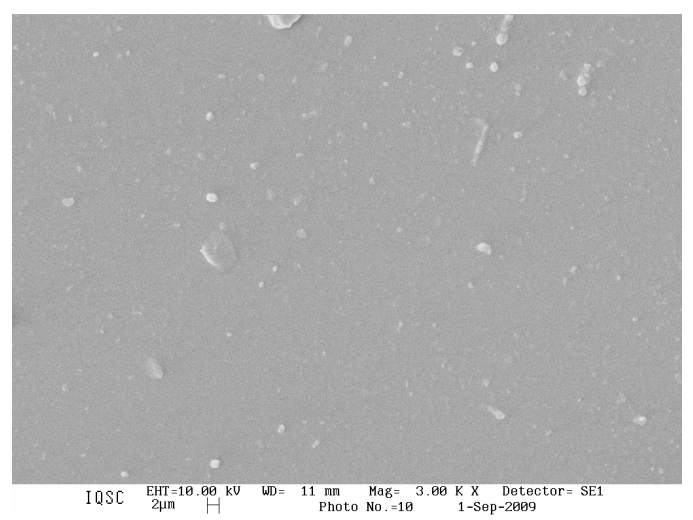

Figura 48 - Micrografia da amostra G5

As micrografias mostradas apresentaram superfícies semelhantes, com presença de pontos mais claros sobre um fundo uniforme e liso. A presença destes pontos poderia ser atribuída a sais não dissolvidos como observado em outros estudos ${ }^{24}$. Contudo como não houve evidências de picos cristalinos nos difratogramas obtidos (Figura 38) não pode se afirmar com certeza a presença das partículas do sal não dissolvido. Além disso, observa-se a presença de pontos mais claros e irregulares que provavelmente são as impurezas aderidas na superfície das amostras devido à exposição dos ESPs em ambiente aberto. As amostras também se mostraram bastante flexíveis, porém não o suficiente para aderir no eletrodo de $\mathrm{TiO}_{2}+$ corante, sendo que o dispositivo de análise de eficiência da conversão de energia solar em elétrica, foi montado com o eletrólito líquido depositado in-situ. 


\subsection{Análise da Eficiência da Célula Solar}

As Figuras 49 e 50 exibem as curvas I x V para os protótipos de célula solar realizados com iluminações de $10 \mathrm{~mW} . \mathrm{cm}^{-2}$ e $100 \mathrm{~mW} . \mathrm{cm}^{-2}$, uma vez, que a eficiência das células solares depende da iluminação ${ }^{12}$. O eletrólito utilizado no dispositivo foi o G4 $\left(9,97 \times 10^{-5}\right.$ S.cm $\left.{ }^{-1}\right)$.

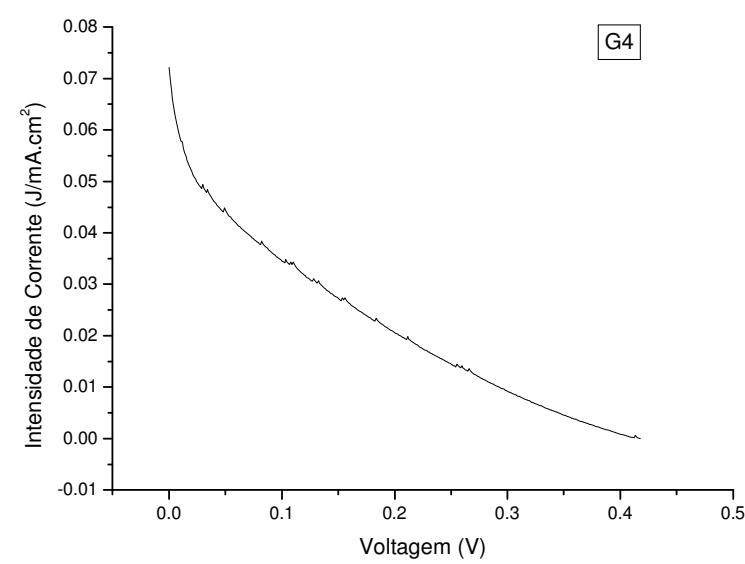

Figura 49 - Curva da intensidade de corrente versus voltagem para a célula solar iluminada com potência de $10 \mathrm{~mW} \cdot \mathrm{cm}^{-2}$.

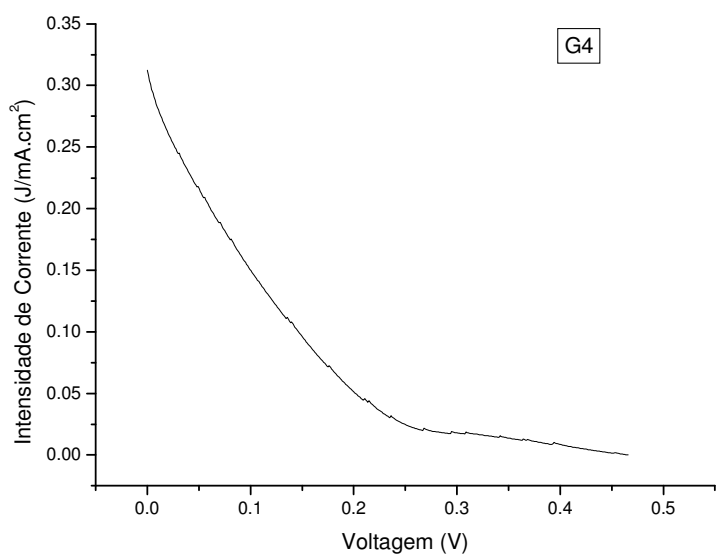

Figura 50 - Curva da intensidade de corrente versus voltagem para a célula solar iluminada com potência de $100 \mathrm{~mW} \cdot \mathrm{cm}^{-2}$.

Estes ensaios revelaram que os comportamentos das curvas não foi o esperado, como em outros sistemas contendo par redox $\mathrm{Lil} / \mathrm{I}_{2}$ i.e. iódicos ${ }^{31}$, fato que pode ser explicado pela dessorção da ftalocianina de ferro pelo eletrólito. Isso ocorreu devido ao solvente $\left(\mathrm{H}_{2} \mathrm{O}\right)$ utilizado para produzir o ESP, uma vez que o mesmo não dissolve totalmente em nenhum outro tipo de solvente. Logo a presença da água facilita a retirada do corante dos sítios da camada de $\mathrm{TiO}_{2}$. Obviamente a eficiência da célula solar ficou comprometida, resultando em $0,15 \%$ para uma iluminação de $100 \mathrm{~mW} . \mathrm{cm}^{-2} \mathrm{e}$ 0,043\% para potência de iluminação de $10 \mathrm{~mW} \cdot \mathrm{cm}^{-2}$.

Um estudo de um novo tipo de corante que utiliza uma matriz solúvel em solventes orgânicos pode possibilitar que as células solares com ESPs à base de gelatina comercial possuam melhores valores de eficiência. 


\section{CONCLUSÃO}

Foram obtidos e caracterizados os eletrólitos sólidos poliméricos à base de gelatina comercial com Lil e $\mathrm{I}_{2}$, intercruzada com formaldeído e plastificada com glicerol. As amostras apresentaram bons valores de condutividade, tendo a Gelatina G4 como o melhor condutor iônico que apresentou valores de condutividade de $9,95 \times 10^{-5} \mathrm{~S}_{\mathrm{cm}} \mathrm{cm}^{-1}$. Todas as amostras na forma de membranas se mostraram predominantemente amorfas e com boas transparências entre 80 e $90 \%$ na região visível do espectro eletromagnético. Também foi verificado que os valores de condutividades aumentam com a temperatura em duas ordens de grandeza de $10^{-5}$ a $10^{-3} \mathrm{~S} . \mathrm{cm}^{-1}$ no intervalo entre a temperatura ambiente e $80^{\circ} \mathrm{C}$. Além disso, estas medidas eram reversíveis após o primeiro ciclo de aquecimento e resfriamento. Os valores de condutividade em função da temperatura revelaram que o mecanismo que governa a movimentação dos íons e do tipo VTF, i.e., com o auxílio de movimentação das cadeias da macromolécula de gelatina o que foi comprovado através dos ajustes com as curvas deste modelo. As amostras submetidas a testes de janela de potencial suportaram potenciais entre $-4,5$ a 4,5 V. As medidas de análises térmicas de DSC revelaram baixos valores de temperatura vítrea, em torno de $-80^{\circ} \mathrm{C}$ para todas as amostras. Esses dados foram usados para obter os valores de energias de ativação que foi de 8,0 a 8,5 kJ. mol ${ }^{-1}$ dependendo da amostra. As análises de microscopia eletrônica de varredura visualizaram as superfícies das amostras que se apresentaram com pontos mais claros devido provavelmente às impurezas introduzidas durante a preparação ou estocagem das mesmas. Por fim os testes de utilização do eletrólito em células solares revelaram baixas eficiências, em torno de $0,15 \%$ devido principalmente ao fato da dissolução do corante e perda de sensibilização da camada de $\mathrm{TiO}_{2}$ por ele exercida. $\mathrm{A}$ solução para este problema é a utilização de um corante solúvel em um dos solventes orgânicos. 


\section{REFERÊNCIAS}

1 WRIGHT P. V. Polymer Electrolytes. British Polymer Journal. v. 7, n. 5, p. 319-327, 1975.

2 RAJEDRAN, S.; SIVAKUMAR, M. Investigations on the effect of various plasticizers in PVA-PMMA solid polymer blend electrolytes. Materials Letters, vol. 58, n. 5, p. 641-649, 2004.

3 GRAY F. M. Solid polymer electrolytes: fundamentals and technological applications.New York: VCH, 1991.

4 RAY, S. S.; BOUSMINA, M. Biodegradable polymers and their layered silicate nanocomposites: in greening the 21st century materials world. Progress in Materials Science, v.50, n. 8, p. 962-1079, 2005.

5 REGIANI, A.; TAMBELLI, C.; PAWLICKA, A.; CURVELO, A. A. S.; GANDINI, A.; LENEST, J. F.; DONOSO, J. P. DSC and solid state NMR characterization of hydroxyethylcellulose/polyether films. Polymer International, v. 49, p. 960-964, 2000.

6 DRAGUNSKI, D. C. Preparação de eletrólitos sólidos poliméricos a partir do amido. 2003. 167 p. Tese (Doutorado) - Instituto de Química de São Carlos, Universidade de São Paulo, São Carlos, 2003.

7 RAPHAEL, E.; AVELLANEDA, C. O.; MANZOLLI, B.; PAWLICKA, A. Agar-based films for application as polymer electrolytes. Electrochimica Acta, 2009. In press.

8 MATTOS, R. I.; PAWLICKA, A.; LIMA, J. F.; TAMBELLI, C. E.; MAGON, C. J.; DONOSO, J. P. Magnetic resonance and conductivity study of gelatin-based proton conductor polymer electrolytes. Electrochimica Acta, 2009. In press.

9 DE WOLF, F. A. Collagen and Gelatin. In: Progress in Biotechnology. 2003. v.23. cap. 5, p. 133-218. ISSN 0921-0423. 
10 DE PAULA, M. Biomateriais injetáveis de colágeno bovino para correções plásticas em geral. São Paulo 2007. Disponivel em: < http://www.freedom.inf.br/artigos tecnicos/21082007/biomateriais.asp > Acesso em dez. 2009.

11 MOHAMAD, A. A.; AROF, A. K. Plasticized alkaline solid polymer electrolyte system. Materials Letters, v. 61, n. 14-5, p. 3096-3099, 2007.

12 VIEIRA, D.; AVELLANEDA, C.; PAWLICKA, A. Conductivity study of a gelatin- based polymer electrolyte. Electrochimica Acta, v. 53, n. 4, p. 1404-1408, 2007.

13 AVELLA, M.; DI PACE, E.; IMMIRZI, B.; IMPALLOMENI, G.; MALINCONICO,M.; SANTAGATA, G. Addition of glycerol plasticizer to seaweeds derived alginates: influence of microstructure on chemical-physical properties. Carbohydrate Polymers. v. 69, n. 3, p. 503-511, 2007.

14 GUÉGUEN, J.; VIROBEN, G.; NOIREAUX, P.; SUBIRADE, M. Influence of plasticizers and treatments on the properties of films from pea proteins. Industrial Crops and Products, v. 7, n. 2-3, p. 149-157, 1998.

15 BABIN, H.; DICKINSON, E. Influence of transglutaminase treatmenton the thermoreversible gelation of gelatin. Food Hydocolloids, v. 15, n. 3, p. 271-276, 2001.

16 MATHLOUTHI, M. (Ed.) Food packaging and preservation: theory and practice. Technology and application of edible protective films. London: Elsevier Applied Science, p. 371-394, 1986.

17 CARVALHO, R. A.; GROSSO, C. R. F. Characterization of gelatin based films modified with transglutaminase, glyoxal and formaldehyde. Food Hydrocolloids. v. 18, n. 5, p. 717-726, 2004.

18 VIEIRA, D.F.; PAWLICKA, A. Optimization of performances of gelatin/libf4 based polymer electrolytes. Electrochimica Acta, 2009.In press. 
19 KROEZE, J. E.; HIRATA, N.; SCHMIDT-MENDE, L.; ORIZU, C.; OGIER, S. D.; CARR, K.; GRATZEL, M.; DURRANT J. R. Parameters influencing charge separation in solid-state dye-sensitized solar cells using novel hole conductors Advanced Functional Materials, v. 16. n. 14, p. 1832-1838, 2006.

20 FREITAS, J. N.; GONÇALVES, A. S.; PAOLI, M. A.; DURRANT, J. R.; NOGUEIRA, A. F. The role of gel electrolyte composition in the kinetics and performance of dyesensitized solar cells. Electrochimica Acta, v. 53, n. 24, p. 7166- 7172, 2008.

21NOGUEIRA, A. F.; LONGO, C.; PAOLI, M. A. Polymers in dye sensitized solar cells: overview and perspectives. Coordination Chemistry Reviews. v. 248, n 13-14, p. 14551468, 2004.

22 FICHEIRO :E. M Spectrum.SVG. Disponível em $<$ http://pt.wikipedia.org/wiki/Ficheiro:EM spectrum.svg.>. Acesso em 14.11.09.

23 SKOOG, D. A.; HOLLER, F. J.; NIEMAN, T. A. Princípios de análise instrumental. 5a ed. Porto Alegre: Ed. Bookman, 2002.

24 SANTOS, L. R. M. Estudo da técnica de espectroscopia de impedância eletroquímica na análise dos copolímeros de enxerto PEBD-g-AAm.1994. $74 \mathrm{f}$. Dissertação (Mestrado) - Faculdade de Engenharia Mecânica, Universidade Estadual de Campinas, Campinas, 1994.

25 MACDONALD, J. R. Impedance spectroscopy: emphasizing solid materials and systems. New York: Wiley Interscience, 1987.

$26 \mathrm{KIM}$, Y. T.; SMOTKIN, E. S. The Effect of plasticizers on transport and eletrochemical proprieties of peo-based electrolytes for lithium rechargeable batteries. Solid State lonics, v. 149, p. 29-37, 2002.

27 CANEVAROLO JR, S. V. Ciência dos polímeros. São Paulo: Artliber, 2002.

28 Callister, W. D. Materials science and engineering: an introduction. 7th ed. New York: John Wiley, 2006. 
29 MICROSCÓPIO Eletrônicos de Varredura (MEV) USP/IF, 2009. Disponível em $<$ http://fap.if.usp.br/ /ff/mev.html>. Acesso em: 28.12.09

30 ALEIXO, L. M. Voltametria: conceitos e técnicas. Instituto de Química, Universidade Estadual de Campinas. Disponivel em: < http://usuarios.upf.br/ gobbi/CADA\%20UMA\%20DAS\%20DISCIPLINAS/QUIMICA\%20 ANALITICA\%20INSTRUMENTAL/voltametria-vf.pdf> Acesso em: 08/01/2010

31 BENEDETTI, J. E.; DE PAOLI, M. A.; NOGUEIRA, A. F. Enhancement of photocurrent generation and open circuit voltage in dyesensitized solar cells using $\mathrm{Li}+$ trapping species in the gel electrolyte. Chemical Communications, v. 7, n. 9, p. 11211123, 2008.

32 CRC handbook of Chemistry and Physics: a ready-reference book of chemical and physical data, 83rd ed. Boca Raton, CRC Press, 2002. 